\title{
Tracing silicon cycling in the Okavango Delta, a sub-tropical flood-pulse wetland using silicon isotopes
}

\author{
Patrick J. Frings ${ }^{\mathrm{a}, *}$, Christina De La Rocha ${ }^{\mathrm{b}}$, Eric Struyf ${ }^{\mathrm{c}}$, Dimitri van Pelt ${ }^{\mathrm{c}}$, \\ Jonas Schoelynck $^{\mathrm{c}}$, Mike Murray Hudson ${ }^{\mathrm{d}}$, Mangaliso J. Gondwe ${ }^{\mathrm{d}}$, Piotr Wolski ${ }^{\mathrm{d}}$, \\ Keotsheple Mosimane ${ }^{\mathrm{d}}$, William Gray ${ }^{\mathrm{e}}$, Jörg Schaller ${ }^{\mathrm{f}}$, Daniel J. Conley ${ }^{\mathrm{a}}$ \\ a Department of Geology, Lund University, Sölvegaten 12, 22362 Lund, Sweden \\ ${ }^{\mathrm{b}}$ CNRS UMR 6539, Institut Universitaire Européen de la Mer, Université de Bretagne Occidentale, Technôpole Brest-Iroise, Place \\ Nicholas Copernic, 29280 Plouzané, France \\ ${ }^{\mathrm{c}}$ Ecosystem Management Research Group, Department of Biology, University of Antwerp, Universiteitsplein 1, Antwerp, Belgium \\ ${ }^{\mathrm{d}}$ Okavango Research Institute, University of Botswana, Private Bag 285, Maun, Botswana \\ ${ }^{\mathrm{e}}$ Department of Geography, University College London, Gower Street, London WC1E 5BT, United Kingdom \\ ${ }^{\mathrm{f}}$ Faculty of Environmental Sciences, Technische Universität Dresden, 01737 Tharandt, Germany
}

Received 15 February 2014; accepted in revised form 8 July 2014; Available online 22 July 2014

\begin{abstract}
Chemical weathering of silicate minerals releases elements into solution whereas the neoformation of secondary minerals works in the opposite direction, potentially confounding estimates of silicate weathering rates. Silicon isotopes $\left(\delta^{30} \mathrm{Si}\right) \mathrm{may}$ be a useful tool to investigate these processes. Here, we present $82 \delta^{30} \mathrm{Si}$ measurements from surface waters, pore waters, biogenic silica (BSi), clays, sand and vegetation from the Okavango Delta, Botswana, a freshwater sub-tropical, flood-pulse wetland. Hydrologically, the Okavango is dominated by evapotranspiration water losses to the atmosphere. It receives an annual pulse of water that inundates seasonal floodplains, while river baseflow is sufficient to maintain a permanent floodplain. $\delta^{30} \mathrm{Si}$ in dissolved silica (DSi) in surface waters along a $300 \mathrm{~km}$ transect at near-peak flood show a limited range $(0.36-1.19 \%$ ), implying the Delta is well buffered by a balance of processes adding and removing DSi from the surface water. A key control on DSi concentrations is the uptake, production of BSi and recycling of Si by aquatic vegetation, although the net isotopic effect is necessarily small since all BSi re-dissolves on short timescales. In the sediments, $\mathrm{BSi} \delta^{30} \mathrm{Si}(n=30)$ ranges from $-1.49 \%$ to $+0.31 \%$ and during dissolution, residual BSi tends towards higher $\delta^{30} \mathrm{Si}$. The data permit a field-based estimate of the fractionation associated with $\mathrm{BSi}$ dissolution, $\varepsilon_{\mathrm{BSi}-\mathrm{DSi}}^{30}=-0.26 \%$, though it is unclear if this is an artefact of the process of dissolution. Clay $\delta^{30} \mathrm{Si}$ ranges from $-0.97 \%$ to $+0.10 \%$, $(n=15$, mean $=-0.31 \%$ oo $)$ and include the highest values yet published, which we speculate may be due to an equilibrium isotope effect during diagenetic transformation of BSi. Two key trends in surface water DSi $\delta^{30} \mathrm{Si}$ merit further examination: declining $\delta^{30} \mathrm{Si}$ in an area roughly corresponding to the permanent floodplains despite net DSi removal, and increasing $\delta^{30} \mathrm{Si}$ in the area corresponding to the seasonal floodplains. We infer that evaporative enrichment of surface waters creates two contrasting regimes. Chemical weathering of low $\delta^{30} \mathrm{Si}$ phases releases low $\delta^{30} \mathrm{Si}$ DSi in the relatively dilute waters of the permanent floodplains, whereas silicon removal via clay formation or vegetation uptake is the dominant process in the more enriched, seasonal floodplains.
\end{abstract}

(C) 2014 Elsevier Ltd. All rights reserved.

\footnotetext{
* Corresponding author.

E-mail address: patrick.frings@geol.lu.se (P.J. Frings).
} 


\section{INTRODUCTION}

Terrestrial silicate weathering consumes atmospheric $\mathrm{CO}_{2}$ and produces a fluvial alkalinity flux which is subsequently precipitated as carbonates in the oceans, countering the continuous input of $\mathrm{CO}_{2}$ to the atmosphere from volcanism and metamorphism (Berner et al., 1983). Weathering rates are related to temperature and atmospheric $\mathrm{CO}_{2}$ concentrations $\left(p \mathrm{CO}_{2}\right)$ (Beaulieu et al., 2010) so silicate weathering comprises a long-term negative feedback on $p \mathrm{CO}_{2}$ (Walker et al., 1981; Berner et al., 1983) helping to maintain habitable global average temperatures over the last few billion years of Earth's history (Sagan and Mullen, 1972). However, the loci of $\mathrm{CO}_{2}$ consumption via silicate weathering remain disputed. Floodplains are receiving attention for their potential role in silicate weathering. The deposition of freshly eroded, highly weatherable material in a system with sediment residence times substantially longer than their upstream source areas creates clear potential for further silicate weathering in the basin (Bouchez et al., 2012). However, mineral neoformation in floodplains has also been inferred (e.g. Humphries et al., 2010; Fontorbe et al., 2013) and may reduce the net solute release. Here, the term mineral neoformation refers to the net production of new minerals from weathering-derived solutes. A key difference from secondary minerals produced during normal weathering processes is that the loci of formation of these neoformed phases are separated spatially and/or temporally from the minerals that produced the solutes. Mineral neoformation can include the 'reverse weathering' reactions postulated in marine environments by Mackenzie and Garrels (1966) that liberate $\mathrm{CO}_{2}$. The impact of mineral neoformation in floodplain environments on river solute fluxes is very poorly understood but potentially significant, since it can induce differential retention of solutes within the fluvial system. In turn, this may confound efforts to quantify and discriminate between silicate and carbonate weathering fluxes that are typically based on elemental stoichiometries or isotope ratios at a catchment exit.

Silicate weathering can be investigated via the geochemistry of river waters that integrate the weathering and biological processes occurring in their catchments (Bricker et al., 2005). Unfortunately, this approach is complicated by the need to assume steady-state, to account for biological activity and to partition elemental or isotopic fluxes between silicate weathering and carbonate weathering, which typically dominates river elemental fluxes but has no long-term $\mathrm{CO}_{2}$ effect. A variety of techniques are used to address these problems (Garrels and Mackenzie, 1967; Gaillardet et al., 1999; Galy and France-Lanord, 1999; Moore et al., 2013) to varying degrees of success, but since Si derives only from silicate weathering, better knowledge of the $\mathrm{Si}$ biogeochemical cycle will be helpful. Si is bioactive and accumulates at weight per cent levels as biogenic silica (BSi) in both phytoplankton and plant species, particularly grasses, where it provides ecological and physiological benefits, e.g. protection against herbivory or increased structural strength (Epstein, 1999; Ma and Yamaji, 2008; Schoelynck et al., 2010; Klancnik et al., 2013). The stable isotopes of $\mathrm{Si}\left({ }^{28} \mathrm{Si},{ }^{29} \mathrm{Si},{ }^{30} \mathrm{Si}\right)$ are a reasonably well-established tool with which to investigate the terrestrial Si cycle, since they fractionate during key transformations such as the production of BSi from DSi and the formation of secondary minerals (Ziegler et al., 2005a,b; Cornelis et al., 2011). They display a relatively large range of ratios in the natural environment, from $-5.7 \%$ to $+4.6 \%$ (Douthitt, 1982; De La Rocha et al., 2000; Basile-Doelsch et al., 2005; Cockerton et al., 2013) and the fractionations associated with between phase transformations are becoming well understood (Opfergelt and Delmelle, 2012). Recent methodological and technological developments mean they can be routinely assessed on micromole quantities at high precision. Combined with knowledge of $\mathrm{Si}$ pools within a system, $\mathrm{Si}$ isotopes have been used to successfully identify processes at work at the scale of large river basins (e.g. Hughes et al., 2011, 2013).

We investigate the usefulness of $\mathrm{Si}$ isotope natural abundances $\left(\delta^{30} \mathrm{Si}\right)$ in waters, clays and BSi to address questions about weathering reactions, mineral neoformation and biological Si cycling in floodplains. We present results from an instructive case study - the Okavango Delta, Botswana, one of the world's largest and most pristine wetland-floodplain systems. The results highlight that disentangling biological activity from weathering processes is not straightforward. Nevertheless, we infer that both weathering and mineral neoformation occur within the Okavango Delta, and that they are broadly separated in space as a result of the hydrological regime. This confirms that silicon isotopes can be a useful tool to track silicate weathering processes and adds to a growing body of literature that identifies floodplains as biogeochemical reactors.

\section{STUDY SITE}

The Okavango Delta is a large $\left(15,000 \mathrm{~km}^{2}\right)$ freshwater wetland in northern Botswana in the Okavango rift zone (ORZ), a graben structure bounded by the active Gomare fault to the north and the Thamalakane and Kunyere faults to the south. The Okavango River rises in the subtropical highlands of Angola (mean annual precipitation = $1300 \mathrm{~mm}$ ), where it receives an annual pulse of water originating from rainfall during the local wet season. The pulse travels downstream and discharges directly into the ORZ, forming a terminal alluvial fan - the Okavango Delta $\left(19.25^{\circ} \mathrm{S}, 22.75^{\circ} \mathrm{E}\right.$; hereafter 'the Delta,' Fig. 1). The floodpulse peaks in Mohembo - the beginning of the Delta - in April-May at $400-1000 \mathrm{~m}^{3} \mathrm{~s}^{-1}$ and in the distal Delta in July to August (Milzow et al., 2009a; Mackay et al., 2011), creating seasonally inundated floodplains, while river baseflow is sufficient to keep the more proximal regions $\left(\sim 6000 \mathrm{~km}^{2}\right)$ of the Delta inundated year round (McCarthy et al., 1989). Strong annual to decadal scale variability in rainfall mean there is no clear demarcation between the permanently and seasonally flooded regions.

The Okavango River supplies $9.2 \mathrm{~km}^{3}$ of water per year and is supplemented by precipitation inputs of $6 \mathrm{~km}^{3}$ over the rest of the semi-arid catchment (mean annual precipitation $=450 \mathrm{~mm}$ ), mostly during the November to March rainy season (McCarthy and Ellery, 1998). Groundwater recharge losses are negligible since the regional aquifers 
$22^{\circ}$

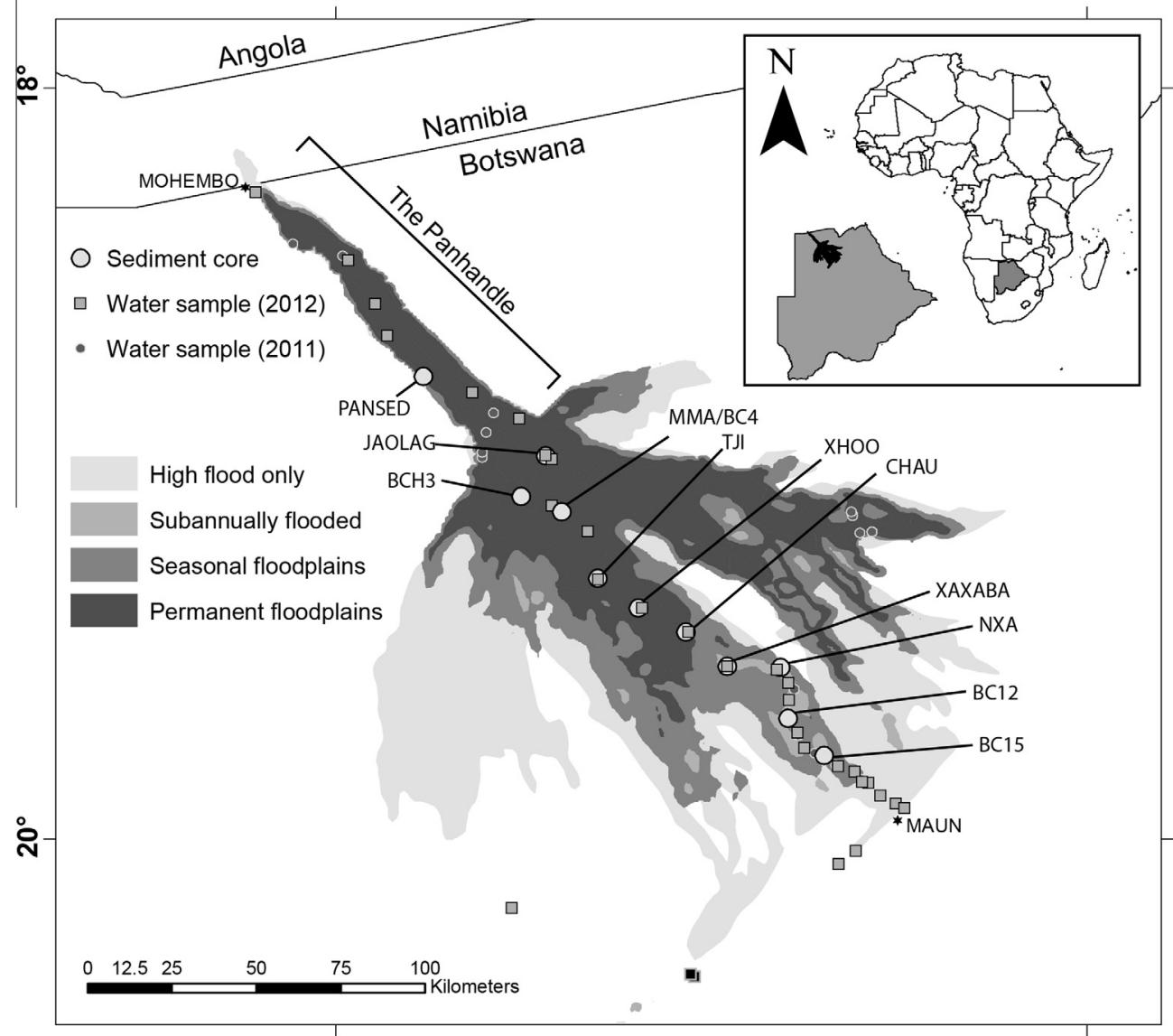

Fig. 1. Map of the Okavango Delta, Botswana, and location of water samples (2011 and 2012) and sediment cores (2012), with permanently and seasonally inundated areas highlighted. Inset: Location of the Okavango Delta in southern Africa.

are saturated, and only $2-5 \%$ of water exits via terminal outflows (Wolski and Murray-Hudson, 2006). The Delta water-balance is therefore dominated by water losses to the atmosphere, meaning almost all inflowing solutes are retained within the system. Inflowing river water is relatively dilute (electrical conductivity, $\mathrm{EC}<40 \mu \mathrm{S} \mathrm{cm}^{-1}$ ), but despite large evapotranspirative water losses it does not become saline, with outflow EC remaining low $\left(\sim 110 \mu \mathrm{S} \mathrm{cm}^{-1}\right)$. It is generally accepted that this is due to solute storage under the numerous islands that mosaic the Delta. Briefly, transpiration from dense vegetation on island fringes lowers the local water-table and creates large hydraulic gradients, drawing water in bulk from the floodplains to the island subsurfaces. Here, the waters do become highly enriched and resulting precipitation of authigenic minerals permanently removes elements from solution (Ramberg and Wolski, 2008; McCarthy et al., 2012), while the more soluble components (e.g. $\mathrm{Na}^{+}, \mathrm{Cl}^{-}$) are conveyed to deeper groundwater by a density fingering process (see Bauer et al., 2006 or Zimmermann et al., 2006 for more detail). Lateral infiltration typically exceeds water-surface evaporation by a factor of 5-9 for a given region (Wolski and Savenije, 2006). The absence of salinisation is therefore due to a partitioning of evapotranspiration skewed towards island surfaces - indeed, floodplain vegetation may even play a role in reducing open water losses through shading (Kihwele et al., 2012). A key point about the authigenic mineral precipitation in the island subsurfaces is that the water flow is a bulk, mass transfer, with no potential for discrimination or for influencing the geochemistry of the remaining surface water (Ramberg and Wolski, 2008; McCarthy et al., 2012).

The Delta surface is characterised by a mosaic of islands, floodplains, lagoons and channels (McCarthy et al., 1997; Mladenov et al., 2005). Conventionally, three hydro-ecological zones of the Delta are recognised (Ramberg et al., 2006) ('hydrotones' in Mladenov et al., 2005 ) that are qualitatively comparable in their hydrological functioning to other tropical, sub-tropical and temperate flood-pulse systems. The Okavango River enters the Delta through the $\sim 100 \mathrm{~km}$ long quasi-riverine 'Panhandle' region (hydrotone I) in the north where it meanders through a narrow $(\sim 25 \mathrm{~km})$, permanently flooded conduit. At the mouth of the Panhandle, the Okavango River debouches into the permanent floodplains (hydrotone II), where it splits into various discrete distributary systems. Water flow slows, vegetation is dominated by Cyperus papyrus and Phragmites australis and typical water depth 
is $\sim 1.5 \mathrm{~m}$. Further downstream, the seasonal floodplains (hydrotone III) experience only episodic water cover and have a larger proportion of islands $(\sim 50 \%)$. Typical water depths are $<1 \mathrm{~m}$. Floodwater here flows mainly though channels bounded by islands and flanking floodplains. Vegetation is typically sparser, and still dominated by C. papyrus and $P$. australis but with greater proportions of emergent grasses, e.g. Miscanthus junceus, Panicum repens and Oryza longistaminata.

Subsurface geology of the $165,000 \mathrm{~km}^{2}$ catchment is dominated by Precambrian/Palaeozoic continental cratons (Jones, 2010) and is nearly entirely overlain by highly weathered Kalahari sands of Cenozoic age, in places $>300 \mathrm{~m}$ deep, whose influence dominates the Okavango River dissolved and suspended loads (McCarthy and Ellery, 1998). The Delta is a low-energy environment reflecting the low gradient (1:3400) and the reworking of Kalahari sand that is responsible for modern Delta topography (McCarthy et al., 1991b). Vegetation in the upstream catchment is mostly Burkea or Brachystegia woodlands and soils are generally thin arenosols (Jones, 2010). The catchment is free of substantial human activity, though water shortages are prompting proposals for damming or water abstraction of the Okavango River in Namibia (Gumbricht et al., 2004).

\section{MATERIALS AND METHODS}

\subsection{Sample collection}

Samples for silicon isotopes were collected during a campaign in September 2012, 1 month after peak flood. A longitudinal transect was taken from the Delta inflow at Mohembo to the outflow streams discharging into the Kalahari. Surface water samples were collected at 38 locations for $\mathrm{Si}$ isotope analysis. They were filtered through $0.45 \mu \mathrm{M}$ Sterivex polycarbonate cartridge filters, acidified and frozen until analysis. Water $\mathrm{pH}$ and conductivity were measured with probes calibrated daily. At 11 sites (see Fig. 1 and Supplementary Table S1), a sediment core between 30 and $90 \mathrm{~cm}$ in length was collected with a modified $75 \mathrm{~mm}$ internal diameter piston corer with a PVC tube, which maintained the sediment-water interface well. At locations with good core recovery, pore-waters were sampled through pre-drilled $2 \mathrm{~mm}$ holes with Rhizon suction samplers (SeebergElverfeldt et al., 2005), transferred immediately to $5 \mathrm{ml}$ vials and frozen. Within $2-3 \mathrm{~h}$, the cores were sub-sectioned at $2 \mathrm{~cm}$ intervals from surface to $20 \mathrm{~cm}$, then $5 \mathrm{~cm}$ intervals thereafter, and frozen before freeze-drying on return to the laboratory. In 2011 vegetation was collected from two sites in the vicinity of the 2012 sediment cores 'NXA' and 'PANSED1' (see Fig. 1) as $0.25 \mathrm{~m}^{2}$ quadrat samples. Samples were collected along a gradient from island centre to floodplain (see Struyf et al., submitted for details), and we consider only the samples collected in open water. In both cases, all above-ground vegetation within $0.25 \mathrm{~m}^{2}$ was collected, oven-dried at $60^{\circ} \mathrm{C}$, weighed (from which biomass density in $\mathrm{kg} \mathrm{m}^{-2}$ was calculated), and homogenised in a mill before analysis of subsamples. We supplement the silicon isotope samples with samples for major cations $(n=30$; Fig. 1) collected opportunistically in a separate campaign in September 2011, where water was filtered, acidified and stored cool until analysis. Where relevant, results are plotted against the straight-line distance from Mohembo. The time elapsed since the flood peak had passed a given sampling point is calculated based on linear interpolation between three monitored water-level gauges within the Delta (data available at http://okavangodata.ub.bw).

\subsection{Laboratory analyses}

\subsubsection{Water}

Major dissolved cation concentrations were determined on the surface (2011) and porewater (2012, after thawing) samples by ICP-AES at Antwerp University or IUEM, Brest, respectively. Selected minor or trace elements (including e.g. Ge, Sr, Rb and $\mathrm{Li}$ ) were analysed by ICPMS (a Thermo Xseries2 in 2011 and a Bruker Aurora M90 in 2012). In 2012, the trace element analysis was performed on an aliquot from the silicon isotope sample. A full treatment of most elements will be published elsewhere (Schaller et al., in prep.); here, the focus is on Ge and the $\mathrm{Ge} / \mathrm{Si}$ ratios since $\mathrm{Ge}$ is a 'pseudoisotope' of $\mathrm{Si}$ (Kurtz et al., 2002) that substitutes into most silicates (Kurtz et al., 2002). However, some biological or pedogenic processes discriminate against $\mathrm{Ge}$ or $\mathrm{Si}$, making the $\mathrm{Ge} / \mathrm{Si}$ ratio complementary to $\delta^{30} \mathrm{Si}$. Measurement of water directly by ICP-MS targets both inorganic dissolved Ge and conservative methylgermanium species so the results represent maximum dissolved $\mathrm{Ge}$ values, though concentrations of organo-germanium complexes are typically an order of magnitude lower than inorganic Ge in freshwaters (Lewis et al., 1988). In samples from 2011, a mass spectrometer with a collision cell to reduce polyatomic interferences was available for measurements, but not in 2012. In 2011, certified reference water from NRC, Canada, was used as a standard, and in 2012 multi-element ICP standards were used (ESSLAB, Essex, UK).

\subsubsection{Sediment and vegetation}

Biogenic silica (BSi) content of sediment and plants was determined on bulk homogenised samples following DeMaster (1991). Briefly, $\sim 30 \mathrm{mg}$ freeze-dried material was digested in $1 \% \mathrm{Na}_{2} \mathrm{CO}_{3}$ at $85^{\circ} \mathrm{C}$ for $5 \mathrm{~h}$. All BSi is assumed to dissolve rapidly, with any further increase in $\mathrm{Si}$ with time due to a constant contribution from mineral silicate dissolution. The $y$-axis intercept of a least-squares linear regression on a time course of aliquots at 3, 4 and $5 \mathrm{~h}$ is accordingly taken as the fraction of the extracted dissolved silica (DSi) deriving from BSi. DSi concentrations in these aliquots were assessed spectrophotometrically after neutralisation and dilution with $0.021 \mathrm{M} \mathrm{HCl}$ using the molybdate-blue reaction (Strickland and Parsons, 1968). This protocol can extract non-biogenic $\mathrm{Si}$ with similar structure, so a more strict terminology identifies it as amorphous $\mathrm{Si}$ (ASi). However, given the abundance of siliceous producers, we retain the term BSi for simplicity and consistency with earlier work. 


\subsection{Silicon isotopes}

\subsubsection{Surface and pore waters}

$\delta^{30} \mathrm{Si}$ was determined on all surface and pore-waters where sufficient $\mathrm{Si}$ (minimum $\sim 2 \mu \mathrm{mol}$ ) was available. As a precautionary measure to redissolve any $\mathrm{SiO}_{2}$ precipitated from frozen samples containing high concentrations of silicic acid (Macdonald and Mclaughlin, 1982), samples were treated after thawing for $>24 \mathrm{~h}$ with $0.5 \mathrm{ml}$ of $2 \mathrm{M}$ $\mathrm{NaOH}$ for $2 \mathrm{~h}$ before re-acidification with $\mathrm{HNO}_{3}$. To minimise matrix effects, sample purification followed a two-step procedure: (1) precipitation of Si with triethylamine molybdate ("TEA-Moly") to form a triethylamine silicomolybdate complex, which is filtered and combusted at $1000{ }^{\circ} \mathrm{C}$ to form a nearly-pure $\mathrm{SiO}_{2}$ polymorph (a mixture of cristobalite and tridymite) (De La Rocha et al., 1996), and (2) dissolution in an excess of $\mathrm{HF}$ to form the $\mathrm{SiF}_{6}^{2-}$ ion and anion exchange chromatography (following Engström et al., 2005), to eliminate any remaining contaminants. All acids were Merck Suprapur grade and all dilutions were made with MilliQ deionised distiled water $\left(18.2 \mathrm{M} \Omega \mathrm{cm}^{-1}\right)$.

\subsubsection{Sediment and vegetation}

Separated BSi, clay (operationally defined as the size fraction smaller than $2 \mu \mathrm{m}$ ) and sand fractions from selected sediment horizons from a series of cores in the permanent and seasonal floodplains (Chau, Xhoo, NXA, JDI; see Fig. 1 for locations) were analysed for $\delta^{30} \mathrm{Si}$. The fractions were separated with standard size and density separation techniques - sieving, differential settling and heavy liquid (sodium polytungstate at $2.3 \mathrm{~g} \mathrm{~cm}^{-3}$ ) separation after $\mathrm{H}_{2} \mathrm{O}_{2}$ pre-treatment to remove the majority of organic matter (Shemesh et al., 1988). The success of the separations was confirmed by inspection of a subset of samples under SEM. The clay-size separates were not observed to contain microquartz particles, consistent with previous grain size analysis of the Kalahari Sands (Lancaster, 1986; Livingstone et al., 1999). The separated fractions were dissolved in $35 \% \mathrm{HF}$ for the clays and sand or $2 \% \mathrm{Na}_{2} \mathrm{CO}_{3}$ at $85^{\circ}$ for $5 \mathrm{~h}$ for the plants and $\mathrm{BSi} .2 \% \mathrm{Na}_{2} \mathrm{CO}_{3}$ (cf. $1 \%$ in our BSi determinations) was used to ensure the complete dissolution of all $\mathrm{BSi}$, while avoiding as far as possible the coincident dissolution of concealed lithogenic contaminants which have been shown to affect oxygen isotope ratios in diatom silica (Brewer et al., 2008). Where residues existed, they were examined with light microscopy to check the completeness of the dissolution. The $\mathrm{Si}$ in solution was then diluted to $\sim 100 \mu \mathrm{M}$, based on the dry mass before dissolution. Fluoride ions inhibit the formation of the triethylamine-silicomolybdate complex by binding with silicic acid: this was avoided by adding an excess of boric acid. The samples were then treated as the water samples above, i.e. following the TEA-Moly precipitation and ion exchange column chemistry.

\subsubsection{Isotope measurements}

$\delta^{30} \mathrm{Si}$ was assessed on $2 \mathrm{ppm} \mathrm{Si}$ solutions in a $\mathrm{HF} / \mathrm{HNO}_{3}$ matrix on a Neptune multi-collector ICP-MS (ThermoFinnigan) operating in dry-plasma mode using either an Apex or a Cetac Aridus II $^{\mathrm{TM}}$ desolvating nebulizer for sample introduction; both introduction systems yielded identical results. The Neptune was operating in medium ('quasi-high') resolution $(m / \Delta m \approx 4000)$ using matrix matched standard-sample bracketing. A correction was made by external standardization using $\mathrm{Mg}$ isotopes to monitor and correct for instrumental mass-bias (Cardinal et al., 2003). Standard operating details can be found elsewhere (e.g. De La Rocha et al., 2011; Fontorbe et al., 2013).

Silicon isotope ratios are presented in delta notation $\left(\delta^{30} \mathrm{Si}\right)$, relative to the standard NBS28: $\delta^{30} \mathrm{Si}=\left[\left(R_{\text {sam }} R_{\text {std }}\right) /\right.$ $\left.R_{\text {std }}\right] \times 1000$, where $R_{\text {sam }}$ and $R_{\text {std }}$ is the ratio of ${ }^{30} \mathrm{Si}$ to ${ }^{28} \mathrm{Si}$ in the sample and in NBS28, respectively. The method typically results in measurement precisions of $<0.1 \%$. The long term precision $(1 \sigma \mathrm{SD})$, including the column chemistry, was $\pm 0.07 \%$, based on 29 separate analyses of the working standard between July 2009 and November 2013. A value of $\pm 0.1 \%$ is used as the uncertainty estimate in this manuscript, unless the error associated with the individual measurement was larger. Individual measurements were accepted only if the sample beam intensity fell within $\pm 15 \%$ of the bracketing standards and the results fell close to the mass-dependent fractionation line in a three-isotope plot of $\delta^{29} \mathrm{Si}$ against $\delta^{30} \mathrm{Si}$. A total of 82 samples meet these criteria (Supplementary Fig. S1).

\section{RESULTS}

\subsection{Surface water}

Delta surface water DSi concentrations increase downstream from inflow values of $\sim 100 \mu \mathrm{M}$ to almost $700 \mu \mathrm{M}$ at the terminal outflows (Fig. 2, Supplementary Table S2). The major cations from $2011\left(\mathrm{Mg}^{2+}, \mathrm{Ca}^{2+}\right.$, $\mathrm{Na}^{+}, \mathrm{K}^{+}$) show similar patterns (Supplementary Fig. S2). The magnitude of downstream enrichment, i.e. the ratio of outflowing (mean of outflow streams) to inflowing (upper Panhandle) concentrations, is variable among elements and decreases in the order $\mathrm{Na}>\mathrm{Mg}>\mathrm{Ca}>\mathrm{Si}>\mathrm{K}$ (Supplementary Fig. S2), suggesting net Si removal relative to e.g. $\mathrm{Na}$, a more conservative element. Unfortunately, a truly conservative ion (e.g. $\mathrm{Cl}^{-}$) is not available.

Ge concentrations in surface water from 2012 are mostly below detection due to polyatomic interferences on Ge resulting from the Ar-plasma. Samples from 2011, analysed where a collision cell could be employed to reduce these interferences, reveal that water enters the Delta with a dissolved Ge concentration of $\sim 3.4 \mathrm{ng} / \mathrm{l} \mathrm{Ge}$. Concentrations decline to approximately $2.0 \mathrm{ng} / 1 \mathrm{Ge}$ in the floodplains then rise slightly to $3.5 \mathrm{ng} / \mathrm{l} \mathrm{Ge}$ in the terminal outflows. Ge/Si ratios decline throughout the Delta, from 0.5 at Mohembo to $0.1 \mu \mathrm{mol} /$ mol in the distal floodplains, with the exception of two anomalously low Si terminal streams at $\sim 0.5 \mu \mathrm{mol} / \mathrm{mol}$ (Fig. 2).

With one exception, $\delta^{30} \mathrm{Si}$ of Delta surface waters fall within the range $0.36-1.19 \%$. The exception at $2.64 \%$ corresponds to an outflow stream that only very sporadically bears water (Murray-Hudson, pers. obs.). Plotted against distance downstream (Fig. 2), trends in $\delta^{30} \mathrm{Si}$ approximate the hydrological zonation of the Delta. Values are stable $(\sim 1 \%)$ in the riverine Panhandle $(0-100 \mathrm{~km})$, decrease by $\sim 0.8-0.4 \%$ by $200 \mathrm{~km}$ in the permanent floodplains, and 

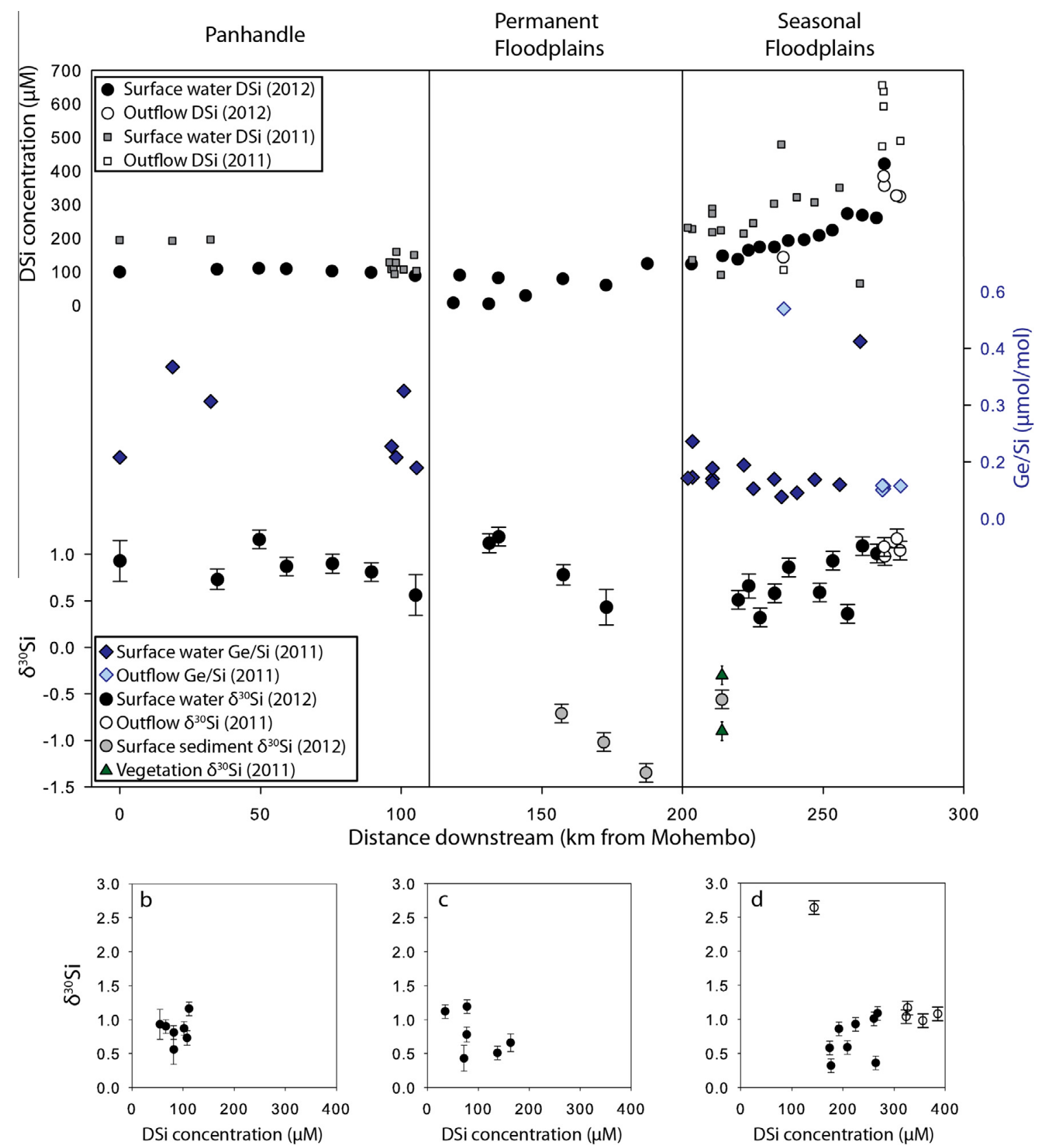

Fig. 2. Downstream changes in surface water geochemistry. Plot (a): (i) dissolved silicate (DSi) concentrations, from both 2012 transect and 2011 samples, (ii) $\mathrm{Ge} / \mathrm{Si}$ ratios (blue circles) from 2011 samples and (iii) $\delta^{30} \mathrm{Si}$ of DSi from 2012 transect samples (one sample at $2.74 \%$ is not shown, see main text for details). Also shown is the $\delta^{30} \mathrm{Si}$ value of surface sediment BSi from the four cores with available data. The figure is split into sections approximating the hydrological zonation of the Delta (Panhandle, permanent floodplains, seasonal floodplains). (b) $\delta^{30} \mathrm{Si}$ vs. DSi in the Panhandle; (c) $\delta^{30} \mathrm{Si}$ vs. DSi in the permanent floodplains and (d) $\delta^{30} \mathrm{Si}$ vs. DSi in the seasonal floodplains.

then increase again to $\sim 1.2 \%$ in the seasonal floodplains. Within these three zones, $\delta^{30} \mathrm{Si}$ shows no significant relationships with DSi concentrations (Fig. 2b-d). 2012 surface water geochemistry results are presented in Supplementary Table S2.

\subsection{Vegetation and sediment cores}

BSi determination on homogenised vegetation quadrats, dominated by $P$. australis, $M$. junceus and $C$. papyrus showed Delta vegetation accumulates $\mathrm{Si}$ at weight- $\%$ levels (0.9-3.4 wt $\% \quad \mathrm{SiO}_{2} ;$ unweighted mean of all quadrats $\left.=2.25 \% \quad \mathrm{SiO}_{2}\right)$, and major cations in substantial amounts (Struyf et al., submitted). Biomass density in the floodplains of the two sites averaged $2.2 \mathrm{~kg} \mathrm{~m}^{-2}$. Sedimentary $\mathrm{BSi}$ concentrations (\%dry weight) decrease with depth in sediment cores in a consistent manner throughout the Delta (Fig. 3a). Typical surface concentrations are $\sim 10 \%$ dry weight and reflect high BSi input from Delta vegetation, diatoms and sponges, but may also include a minor 
contribution from inorganic amorphous $\mathrm{Si}$ (ASi) phases. Light microscopy indicated the BSi pool is mostly diatoms and phytoliths, with a small contribution from sponge spicules. Concentrations of BSi approach zero in all cores at a depth that corresponds to a sharp visual transition to almost entirely sand/quartz sediments, typically around $20 \mathrm{~cm}$ (Fig. 3a). Assuming a typical sedimentation rate in the neighbourhood of $0.20 \mathrm{~cm}_{\text {year }}^{-1}$ (Bernal and Mitsch, 2013), this implies complete BSi dissolution occurs on sub-centennial timescales.

Porewater elemental profiles (Fig. 4a) are variable. In an environment dominated by dissolution and diffusion, it may be expected to see an asymptotic behaviour (House et al., 2000) but that is generally not the case. In some cases (JAO, NXA, see Fig. 1 for site locations) the porewater DSi concentrations are relatively invariant with depth and the DSi concentrations are low enough to be occasionally at or below the concentration of surface waters, implying net removal of DSi. Other sites (Xhoo, Chau), have more classical profiles, with DSi concentrations reaching an asymptote at $\sim 800 \mu \mathrm{M}$, near the solubility of ASi. Few $(n=5)$ porewater samples met our measurement inclusion criteria, but have $\delta^{30} \mathrm{Si}$ values with mean $0.30 \%$ (Fig. 4b).

\subsubsection{Sediment separates and vegetation $\delta^{30} \mathrm{Si}$}

$\delta^{30} \mathrm{Si}$ of Delta sands are constant throughout the Delta at $-0.17 \pm 0.1 \%$ o $(n=6$; Fig. 5$)$, in line with our understanding that Delta geomorphology broadly reflects reworking of homogenous Kalahari sands (McCarthy et al., 1991a). $\delta^{30} \mathrm{Si}$ of separated BSi and clay fractions from the sediment display larger variation. BSi separates $(n=33)$ range from -1.48 to $0.34 \%$. The surface sediment $\mathrm{BSi} \delta^{30} \mathrm{Si}$ values display a downstream decline that parallels the trend in the surface water over the same distance - i.e. a drop of $\sim 0.8 \%$ over $\sim 100 \mathrm{~km}$. Two monospecific vegetation samples of the dominant species of the Delta ( $C$. papyrus and $P$. australis) collected in September 2011 at Nxaraga (NXA) have bulk $\delta^{30} \mathrm{Si}$ values of $-0.90 \%$ and $-0.30 \%$, respectively. Assuming surface water DSi $\delta^{30} \mathrm{Si}$ at that location in 2011 as in 2012 (i.e. $\sim 0.5 \%$ ), then this approximates fractionations, ${ }^{30} \varepsilon$, of $-1.4 \%$ and $-0.8 \%$, respectively roughly in line with earlier studies on rice (Orzya) and banana (Musa) (Opfergelt et al., 2006; Ding et al., 2008). The $\mathrm{BSi} \delta^{30} \mathrm{Si}$ in near-surface sediments $(4-6 \mathrm{~cm}$, $-0.56 \%$ ), presumed to represent net biological uptake at the same location is consistent with the vegetation. Moving downcore, $\delta^{30} \mathrm{Si}$ of $\mathrm{BSi}$ consistently increases with depth (Fig. 3b), i.e. is negatively related with BSi concentrations.

The $\delta^{30} \mathrm{Si}$ of clay separates $(n=15)$ ranges between -0.97 and $0.10 \%$, (mean $-0.34 \%$ ), and also tend towards higher values with depth (Fig. 5). They show no consistent lateral variation and are always lighter than the overlying surface water.

\section{DISCUSSION}

Variations in surface water $\delta^{30} \mathrm{Si}$ of DSi integrate the cumulative effects of many processes. To explain these variations, we start from the understanding that $\mathrm{Si}$ in the surface water is fractionated by processes that transform $\mathrm{Si}$ from solid to solution or vice versa. We discuss possible processes and their impact within the Delta, and then
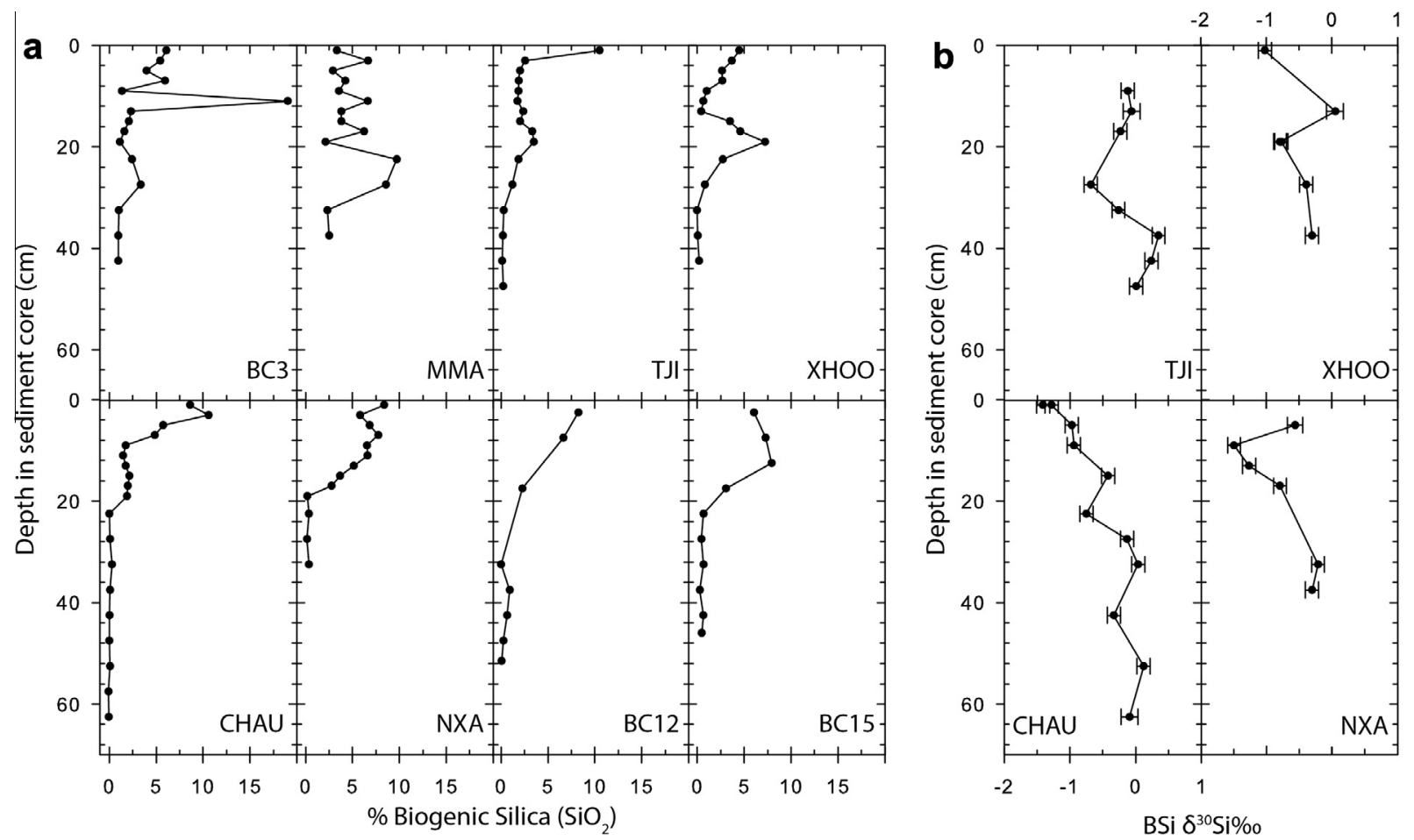

Fig. 3. Biogenic silica separates in the Okavango floodplain sediments: (a) variation of Si concentrations (\% dry weight) with depth in sediment cores; (b) $\mathrm{Si}$ isotope ratios in residual $\mathrm{BSi}$ of sediment cores. 


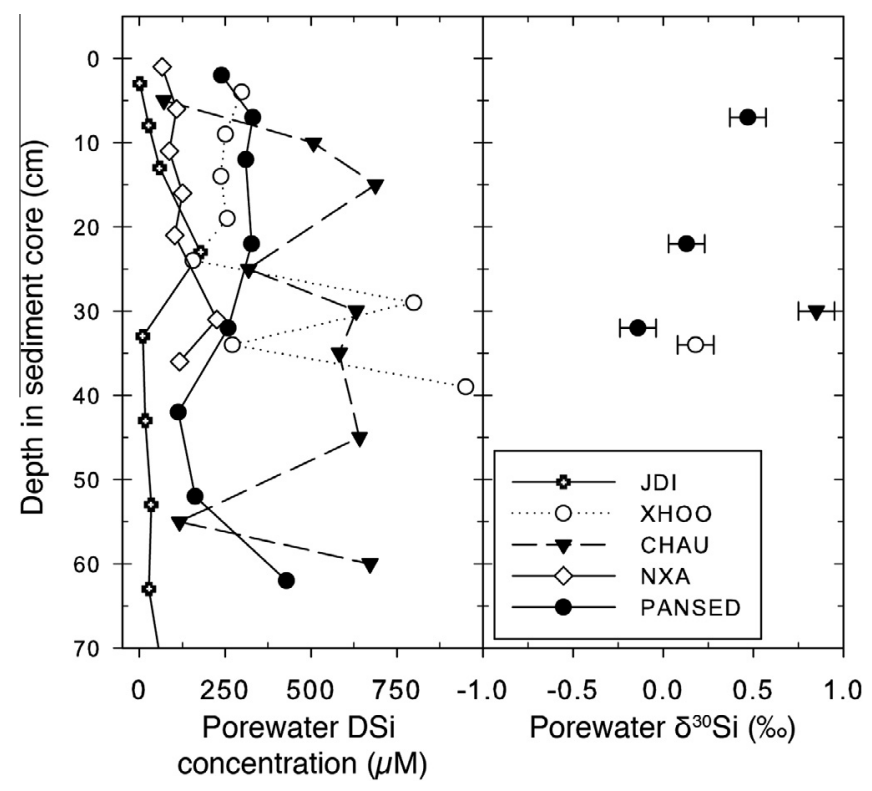

Fig. 4. Porewater of the Okavango floodplains: Left: downcore variation in porewater dissolved silica concentrations $(\mu \mathrm{M})$ for different sediment cores. Right: $\mathrm{Si}$ isotope ratios for porewater samples.

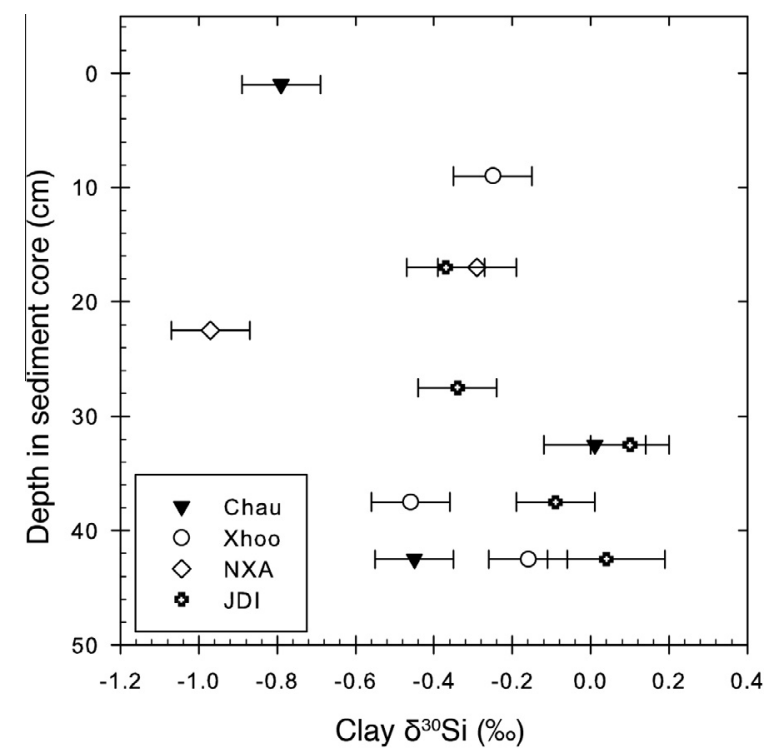

Fig. 5. Variation with depth below sediment surface of $\delta^{30} \mathrm{Si}$ of separated clay fraction from sediment cores. Also plotted (above) is the range of $\delta^{30} \mathrm{Si}$ values shown by the homogenous sand fraction in the Okavango Delta.

search for a physically plausible, internally consistent combination that can explain both the surface water $\delta^{30} \mathrm{Si}$ variations and the variations seen in the BSi, clays and porewaters.

We know, a priori, that DSi must be being biologically removed from solution because of the presence of a vast and accumulating BSi pool in vegetation and other aquatic organisms (Section 5.1). We also know DSi must also be being returned to solution as we observe rapid dissolution of the sediment BSi pool (Fig. 3 and Section 5.2).
Additionally, we know there is the possibility for both DSi release (weathering) and consumption (mineral neoformation) (Sections 5.3 and 5.4), sensu lato, to occur within the Delta. Finally, we know that there are no external (groundwater or rainwater) DSi inputs during the time of our sampling, and that in the absence of other workable hypotheses (Section 6) some combination of these four processes must combine to produce the observed trends.

\subsection{Vegetation BSi production}

There is a large and dense vegetation Si-pool in the Delta. Estimation of the size and production rate is difficult, but based on our measurements of vegetation density $\left(\sim 2.2 \mathrm{~kg} \mathrm{~m}^{-2}\right.$ in inundated areas), and vegetation BSi content (unweighted mean of all quadrats $=2.25 \%$ dry biomass), using a floodplain area of $12,000 \mathrm{~km}^{2}$ and assuming twice annual replenishment of the biomass after McCarthy et al. (1989), we arrive at an annual production $9.9 \mathrm{Gmol} \mathrm{year}^{-1}$. For comparison, taking $100 \mu \mathrm{M}$ DSI as a mean value of inflow concentrations at Mohembo (no monitoring data are available), and a mean annual water input of $9.2 \mathrm{~km}^{3}$ (Section 2) $0.9 \mathrm{Gmol}$ DSi enters the Delta through the Okavango River on an annual basis. This suggests the majority of new BSi production is actually supported by dissolution and recycling of 'old' BSi.

Assuming a floodplain water loss rate of $4 \mathrm{~mm} \mathrm{day}^{-1}$ (Gieske, 1997; Bauer et al., 2004; Milzow et al., 2009b), evapotranspiration should result in solute enrichment in the permanent floodplains (Sawula and Martins, 1991). However, elemental concentrations, including DSi, remain relatively constant or even decrease (Fig. 2). Note that the possibility that the older water had lower original DSi concentrations (Section 6) cannot be completely discounted. Given the high biomass density of the Okavango vegetation, which was at its fullest expansion at the time of 
sampling, we assume the lower DSi concentrations than expected are due to the net vegetative removal of DSi from the surface waters.

Vascular plant species discriminate against the heavier isotopes of $\mathrm{Si}$ during uptake at the root-interface (Opfergelt et al., 2006; Ding et al., 2008; Delvigne et al., 2009), and consequently the isotopic composition of the two bulk mono-specific, above ground vegetation samples $\left(-0.90 \%\right.$ and $-0.30 \%$ ) have lower $\delta^{30} \mathrm{Si}$ values than the surface water at that point $(\sim 0.6 \%)$. The difference of $0.6 \%$ between the two species warrants further explanation. It may be due to (i) differences in within plant Si partitioning (i.e. root vs. shoot $\mathrm{Si}$, since we collected above-ground vegetation only); (ii) different rooting depths or seasonal growth patterns, so that the plants access a different $\mathrm{Si}$ source, or (iii) different fractionations, which can vary between species (Opfergelt et al., 2006) and also with plant growth stage (Ding et al., 2008). While we cannot attribute the difference with certainty to one of these reasons, the results are consistent in direction and magnitude with those observed elsewhere. However, without knowledge of species' distributions, densities, growth rates and fractionations, it is difficult to quantify the impact of the biological uptake on the $\delta^{30} \mathrm{Si}$ of the DSi in the surface water, beyond that the $\delta^{30} \mathrm{Si}$ of the residual DSi should increase as DSi is removed through biological uptake.

\subsection{BSi dissolution in sediments}

The recycling of Si from plant litter is an important step in the Si cycle (Struyf et al., 2007; Schaller and Struyf, 2013) and controls the availability of DSi for new production in the Delta. In all Okavango sediment cores, BSi content declines with depth from the sediment surface and approaches zero (Fig. 3a). This implies that net long-term storage of $\mathrm{Si}$ within the sediments of the inundated floodplains is negligible, and that $\mathrm{Si}$ is efficiently recycled in a thin upper layer of sediment, consistent with our inferences from the size of the vegetation pool (see above). Since the $\mathrm{BSi}$ fraction of the sediment has low $\delta^{30} \mathrm{Si}$ (Section 4.2.1), then dissolution of this will re-input isotopically light DSi into the system, once any potential fractionation is accounted for.

\subsubsection{Fractionation during dissolution of BSi?}

$\delta^{30} \mathrm{Si}$ of sediment BSi consistently increases with depth in the sediment as the BSi content approaches zero, compatible with an isotopic fractionation against the heavier isotopes during dissolution and consistent in direction with that observed in laboratory seawater batch experiments (Demarest et al., 2009; Sun et al., 2014). It is possible to estimate the amount of fractionation needed to explain the downcore increase in the $\delta^{30} \mathrm{Si}$ of $\mathrm{BSi}$, assuming this change is entirely due to isotopic fractionation during dissolution. If $\mathrm{BSi}$ production is relatively consistent in magnitude and isotopic composition at a given location, the ratio of $\mathrm{BSi}_{X} / \mathrm{BSi}_{\text {surf }}$ provides a depth-specific estimate of $f$, the fraction of initial BSi remaining at depth $X$. The change in the $\delta^{30} \mathrm{Si}$ (i.e. $\Delta \delta^{30} \mathrm{Si}$ ), defined as $\delta^{30} \mathrm{Si}_{\text {residual }}-$ $\delta^{30} \mathrm{Si}_{\text {initial }}$ accounts for the downstream variation in $\delta^{30} \mathrm{Si}$.
The apparent fractionation, $\varepsilon_{\mathrm{BSi}}^{30}$, associated with $\mathrm{BSi}$ dissolution can then be calculated from the gradient of the plot of $\ln (f)$ against $\Delta \delta^{30} \mathrm{Si}$ (Fig. 6) (via rearranging Eq. (1); Mariotti et al., 1981):

$\delta^{30} \mathrm{Si}_{\text {residual }}=\delta^{30} \mathrm{Si}_{\text {initial }}+\varepsilon \ln f$

We obtain $\Delta \delta^{30} \mathrm{Si}=-0.26 \pm 0.04 \ln (f)-0.13 \pm 0.09$, $\left(r^{2}=0.64, p<0.01\right)$. When the regression is forced through the origin (i.e. $\Delta \delta^{30} \mathrm{Si}=0$ when $f=1$ ), the gradient $\varepsilon_{\mathrm{BSi}}^{30}=$ $-0.22 \%$. This is less than Demarest et al. (2009) and Sun et al. (2014) who found -0.55 and $-0.80 \%$, respectively, from laboratory experiments. Uncertainty in estimating $f$ and $\Delta \delta^{30} \mathrm{Si}$ notwithstanding, it is unclear if the shift here represents true isotope fractionation during dissolution rather than a change in the $\delta^{30} \mathrm{Si}$ of the material exposed for dissolution as the $\mathrm{BSi}$ is progressively solubilised. Wetzel et al. (2014) find no analytically resolvable isotope fractionation during dissolution of homogenous size fractions of marine $\mathrm{BSi}$ in $5 \mathrm{mM} \mathrm{NaOH}$. However, shifts in the $\delta^{30} \mathrm{Si}$ of DSi released over time from a heterogeneous BSi sample may be related to changes in which subset of the sample was dissolving. The BSi fractions in the sample (e.g. phytoliths, diatoms or sponges) do not necessarily have the same initial $\delta^{30} \mathrm{Si}$ values and may dissolve at different rates due to variability in their relative surface areas, thicknesses or structures. Alternatively, there may be variable isotope distribution within the BSi itself, related to rates and/or mechanisms of silification. This introduces the potential for the apparent occurrence of $\mathrm{Si}$ isotope fractionation that is in fact an artefact of the dissolution pathway. Thus whether or not silicon isotopes are fractionated during biogenic silica dissolution remains under debate. Although the first directed study appears to show isotope fractionation (Demarest et al., 2009), it has not been noted

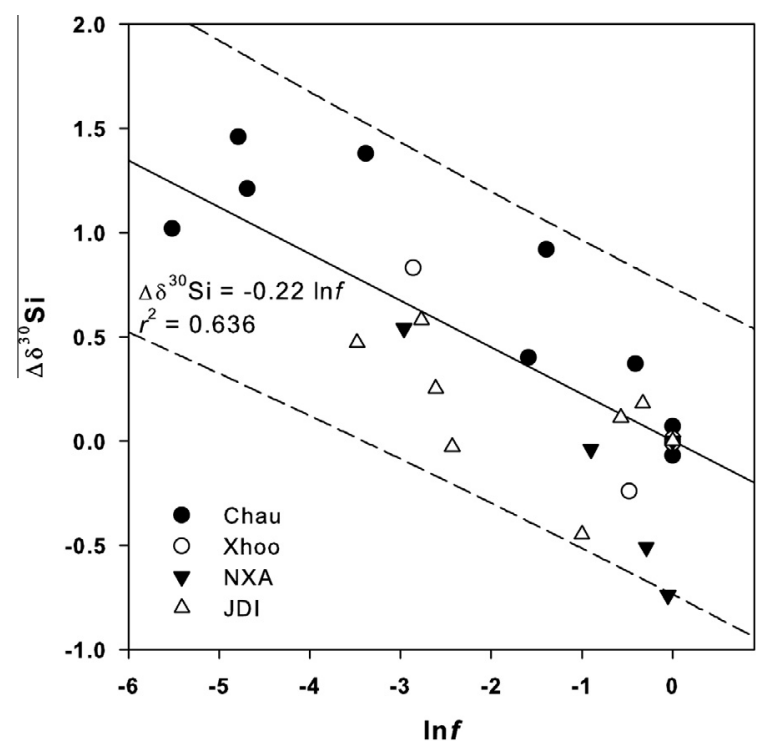

Fig. 6. Apparent fractionation of silicon isotopes during dissolution of BSi (decreasing $\ln f$ ). Solid black line is a linear least-squares regression through the origin $\left(\Delta \delta^{30} \mathrm{Si}=0\right.$ at $\left.f=1\right)$ with gradient -0.22 . If the regression is not forced through the origin, the gradient becomes -0.26 . Dashed lines are $95 \%$ prediction intervals. 
elsewhere (e.g. De La Rocha et al., 1998; Wetzel et al., 2014). Our data do not permit resolution of this issue, but in either case, dissolution of BSi will constitute a DSi source with low $\delta^{30} \mathrm{Si}$. That this is not observed in all the porewater silicon isotopes likely reflects the multiple processes acting on the isotope values, including the reuptake of $\mathrm{Si}$ by vegetation.

\subsection{Weathering}

There is certainly potential for chemical weathering the release of solutes from minerals - to occur in the Delta. Annually, it receives significant quantities of sediment: 170,000 tons of bedload and 39,000 tons of suspended sediment (McCarthy and Ellery, 1998; Gumbricht et al., 2005). It also receives dust inputs of $\sim 250,000$ tons per year (Garstang et al., 1998; Krah et al., 2006). River bedload is mainly quartz, the suspended load mainly kaolinite and phytoliths, while the composition of dust input is unconstrained, but biased towards small size fractions (Humphries et al., 2014) and could include a phytolith or other BSi component. The potential for floodplain weathering is well demonstrated. For example, based on river solute budgets, Galy and France-Lanord (1999) show floodplain weathering contributes to the weathering flux in the Ganges basin, corroborated by a later study showing sediments carried by the Ganges do indeed become progressively weathered as they cross the alluvial plain (Lupker et al., 2012). The same is observed in the Amazon, based on both river sediments (Bouchez et al., 2012) and the demonstration that floodplain alluvial deposits show increasing signs of chemical weathering with age (that is, depth in a sedimentary profile) (Johnsson and Meade, 1990).

In the Okavango, by far the most abundant primary mineral is quartz, which dissolves congruently. Otherwise, the minerals available for dissolution are the riverborne clays and phytoliths, and the unconstrained dust component. Evidence for weathering in the Delta comes from the undersaturation of the waters with respect to common minerals. The solubility of quartz at the temperatures and $\mathrm{pH}$ of typical Okavango water $\left(25^{\circ} \mathrm{C}, \sim 6.3\right)$ is around $100 \mu \mathrm{M}$, i.e. less than surface water DSi concentrations, so substantial quartz dissolution is unlikely to occur and in any case would proceed incredibly slowly. At least for the upper Delta, waters are undersaturated with respect to secondary minerals like kaolinite and various smectites (discussed in Sawula and Martins, 1991). In general, the cation-deplete nature of the minerals available for dissolution suggests any chemical weathering in the Okavango is not a locus of $\mathrm{CO}_{2}$ consumption.

So if floodplain weathering is occurring, what might its impact be? Ultimately, the $\delta^{30} \mathrm{Si}$ of the DSi released depends on the nature of the weathering reaction and the $\delta^{30} \mathrm{Si}$ of the dissolving mineral. A (net) weathering reaction can be either congruent (stoichiometric), or incongruent (non-stoichiometric), in which case the original mineral is modified to produce both solutes and a secondary solid phase. This suggests that with increasing weathering intensity (completeness of weathering) the $\delta^{30} \mathrm{Si}$ being released to solution is likely to change: in the case of congruent weathering, the isotope ratio of the DSi released must equal that of the original mineral, while incongruent weathering gives rise to potential $\mathrm{Si}$ isotope fractionation. Globally, since few weathering reactions proceed congruently, the $\delta^{30} \mathrm{Si}$ of river $\mathrm{DSi}$ is consistently higher than that of the minerals it derives from because of preferential partitioning of the lighter isotopes into secondary phases, giving them a relatively low $\delta^{30} \mathrm{Si}$ value (Douthitt, 1982; Ding et al., 1996; De La Rocha et al., 2000; Ziegler et al., 2005b; Opfergelt et al., 2010). Incongruent weathering of primary silicate minerals is therefore likely to produce an input of DSi with relatively high $\delta^{30} \mathrm{Si}$ and a corresponding clay component with a relatively lower $\delta^{30} \mathrm{Si}$. Conversely, the complete breakdown of most primary minerals would introduce a DSi component with $\delta^{30} \mathrm{Si}$ in the neighbourhood of $-0.2 \%$ (Savage et al., 2013). Finally, complete breakdown of secondary minerals would be expected to produce a low $(-1.0 \%$ to $-2.5 \%$ o component (Cornelis et al., 2011).

Some of the lowest river DSi $\delta^{30} \mathrm{Si}$ values ever observed, $\sim 0 \%$, derive from organic matter rich rivers draining wetlands in the Congo basin (Cardinal et al., 2010), an observation repeated in the Amazon (Hughes et al., 2013). These streams are rich in dissolved organic matter (DOM), which creates conditions conducive to the destruction of clays through the action of organic acids (Viers et al., 1997; Oliva et al., 1999). While the Okavango is not an analogous 'black-water' system, it does have high DOM levels (occasionally as high as $25 \mathrm{mg} \mathrm{Cl}^{-1}$ ) in surface waters (Mladenov et al., 2005; Mladenov et al., 2007; Cawley et al., 2012) and presumably higher still in porewaters. This DOM is particularly enriched in fulvic acids, highlighting the plausibility of secondary mineral dissolution that would introduce low $\delta^{30} \mathrm{Si}$ DSi into the Delta, provided the waters are undersaturated with respect to a given mineral.

\subsection{Mineral neoformation}

The neoformation of secondary solid phases from solutes separated in time or space from the parent mineral(s) they derive from - is potentially an important control on Okavango surface water geochemistry. Mineral neoformation can proceed through a variety of mechanisms, including crystallisation of poorly ordered (alumino)silicates, diagenetic incorporation of cations into (alumino)silicates (cf. Mackenzie and Garrels, 1966; Michalopoulos and Aller, 1995) and abiotic mineral precipitation (cf. Righi and Meunier, 1995). Both of these processes produce new clay minerals, and can liberate $\mathrm{CO}_{2}$ in some instances.

Besides soils and nearshore marine sediments (Michalopoulos and Aller, 1995; Righi and Meunier, 1995), clay mineral neoformation has been identified in many fluvial settings, notably in solute rich, saline and/or alkaline environments (Bauer et al., 2006; Furquim et al., 2010a,b; Souza-Júnior et al., 2010; Bristow and Milliken, 2011; McCarthy et al., 2012). In freshwater environments, potentially authigenic smectites are observed in a floodplain of the Mkuze, South Africa (Humphries et al., 2010, 2011). In other river systems, and using just examples based on silicon isotopes, clay neoformation in the floodplains and/ or tributaries is invoked to explain observations in the Nile 
(Cockerton et al., 2013), the Ganges (Fontorbe et al., 2013), the Congo (Cardinal et al., 2010) and the Scheldt (Delvaux et al., 2013).

In the Delta, the clay minerals are heterogeneous with respect to their silicon isotope composition: we see both lateral variability and a downcore increase in clay $\delta^{30} \mathrm{Si}$, suggesting source mixing. Assuming a purely allochthonous clay assemblage, any lateral variations in clay $\delta^{30} \mathrm{Si}$ could be explained by size-dependent hydrodynamic sorting and/or variable dust deposition, although these are unsatisfactory explanations. It is harder to explain the observed downcore heterogeneity in clay $\delta^{30} \mathrm{Si}$ (Fig. 5) without invoking neoformation from porewater solutions (either by diagenetic transformation of an $\mathrm{ASi}$ precursor or by mineral precipitation).

Porewater chemistries substantiate the plausibility of clay neoformation in the Delta. Kinetic precipitation rates and solubilities for the clays found in the Delta (mainly kaolinite and smectites; McCarthy et al., 1989) are poorly defined (e.g. Yang and Steefel, 2008; Maher et al., 2009), so we do not apply saturation indices here. However, soil environments where clays are observed to form have similar solution chemistries to Delta porewaters (e.g. Maher et al., 2009; White et al., 2009). Crucially, the Ge/Si ratios of Delta porewaters are low ( $\mathrm{Ge}$ is below detection in $>80 \%$ of samples, despite large DSi enrichments), suggesting active incorporation of Ge into secondary phases, consistent with observations from soils (Kurtz et al., 2002; Scribner et al., 2006).

At $-0.97 \%$ to $+0.10 \%$ (mean $=-0.34)$ clay $\delta^{30} \mathrm{Si}$ values in the Delta are close to the bulk silicate earth and broadly inconsistent with earlier observations. Published $\delta^{30} \mathrm{Si}$ values for the clay fraction of soils and sediments span a larger and generally more negative range of -2.95 to -0.3 (mean of 60 samples $=-1.77 \%$ from Ding et al., 1996; Ziegler et al., 2005b; Cornelis et al., 2010; Opfergelt et al., 2010; Steinhoefel et al., 2011; Opfergelt et al., 2012) which are consistently lower than their parent bedrock because of fractionation during their formation (Section 5.2.1). The exact fractionations during clay formation remain poorly defined, partially because clay formation is not a single process for which an "unadulterated" fractionation may be measured (the dissolution and precipitation steps inherent in weathering may conceivably both have fractionations). Further, repeated cycles of dissolution and re-precipitation, i.e. repeated distillation of isotopes with occasional export of some of the altered material could push the isotopic composition in one or the other direction (cf. Basile-Doelsch et al., 2005).

Nonetheless, different clay minerals appear to have different net fractionations and estimates exist, compiled in Opfergelt et al. (2012), based on the difference in $\delta^{30} \mathrm{Si}$ between the primary silicate mineral and the clay. They suggest fractionation $\left(\varepsilon_{\text {primary-clay }}^{30}\right)$ in the range of $-1 \%$ to $-2 \%$. Crudely, applying this to Delta clays requires a parent phase of $0-2 \%$, above most primary minerals, but consistent with (a) Delta surface water as the DSi source or (b) much lesser fractionation than previously observed, which seems unlikely. However, this is not entirely satisfactory: it seems likelier clays would form in the sediments, where solution geochemistry is more conducive to precipitation and substrates/nuclei more abundant. The available porewater DSi $\delta^{30} \mathrm{Si}$ values are inconclusive (mean $=0.30 \%$ ), although considerably greater than BSi from which they presumably derive. Interpretation of porewater values is complicated because they integrate multiple processes of uncertain magnitudes (Pogge von Strandmann et al., 2012).

\subsubsection{Equilibrium isotope fractionation during diagenetic alteration}

The above assumes that the incorporation of DSi into a neoformed mineral is a kinetic isotope effect, as 'normal' clay precipitation presumably is and has been demonstrated for a clay-precursor pathway (Oelze et al., 2014), making high $\delta^{30} \mathrm{Si}$ clays hard to explain. However, we speculate that an alternative mechanism may be the incorporation of DSi into a BSi substrate, and that this is instead a surface process that exhibits an equilibrium isotope effect. In this case, the heavier isotopes will partition towards the stronger bonds, i.e. in the solid (Bigeleisen, 1965). The impact of equilibrium isotope effects depends on the depth to which isotope exchange occurs (Pearce et al., 2012). This speculative mechanism is not dissimilar to the reverse weathering mechanism of Mackenzie and Garrels (1966) in marine environments. Importantly, the magnitude or even presence of this effect in freshwater systems, let alone any associated isotopic fractionation has never been studied. Oelze et al. (2014), through extrapolation of rate dependent kinetic fractionation factors to a zero-net reaction rate, derived an slightly negative equilibrium isotope fractionation factor $\varepsilon^{30}=-0.3 \%$ for the absorption/desorption of $\mathrm{Si}$ onto $\mathrm{Al}$ hydroxide. We suggest diagenetic equilibration of Si warrants further study and that it offers a coherent explanation for the occurrence of some of the highest $\delta^{30} \mathrm{Si}$ clays measured to date.

Discounting secondary phases produced during in-situ primary mineral weathering as a significant source of clays in the Delta because of limited mineral supply, three potential sources of clays remain: (1) allochthonous, i.e. river- or windborne; (2) neoformed direct precipitation from a saturated solution or (3) neoformed by diagenetic transformation of BSi. The final assemblage reflects mixing of all components in uncertain ratios, which formed from precursor phases of uncertain $\delta^{30} \mathrm{Si}$ with uncertain fractionations, so we can only qualitatively assess the impact of mineral neoformation on the surface water DSi. If it does proceed by the diagenetic transformation mechanism of $\mathrm{BSi}$, with the equilibrium isotope effect that we posit to explain the high $\delta^{30} \mathrm{Si}$ clays, then the heavier isotopes will be preferentially removed from solution. Conversely, the proportion of mineral neoformation that proceeds by precipitation from a saturated solution, presumably with a kinetic fractionation effect $\varepsilon_{\text {clay }}^{30}$ in the region of $-1 \%$ to $-2 \%$ (Section 5.4 ), will leave a solution enriched in the heavier isotopes.

\section{ALTERNATIVE MECHANISMS FOR VARYING SURFACE WATER $\delta^{30}$ SI}

An alternative hypothesis interprets downstream variations as changing inputs from the Okavango River that 
are lagged in a manner that reflects the slow transit time of the flood pulse in the Delta - i.e. the water gets progressively older downstream. However, surface-sediment BSi $\delta^{30} \mathrm{Si}$ (Fig. 2), which records a 'surface water plus fractionation' signal integrated over the growing season tracks the surface water trend in the permanent floodplains, strongly suggesting the trend is a consistent feature of the Delta and invariable with changing inputs.

Variations in river geochemistry are typically interpreted as two or more component mixing. Generalising, groundwater (baseflow) is a high DSi, high $\delta^{30} \mathrm{Si}$ component and overland and/or soil water is a low DSi, low $\delta^{30} \mathrm{Si}$ component (e.g. Georg et al., 2006). The annual hydrological cycle induces changes in the relative contributions of these (or other) components, with resultant changes in riverine silicon isotopes. Peak discharge at the inlet in $\sim$ April therefore likely corresponds to the lower $\delta^{30} \mathrm{Si}$ values, as observed in temperate, arctic and tropical rivers (Georg et al., 2006; Engstrom et al., 2010; Hughes et al., 2011; Pokrovsky et al., 2013). While changing river inputs cannot be completely disentangled, such a mechanism must have a small overall impact in the dataset presented here since sampling occurred between 25 and $\sim 125$ days after the peak water pulse had passed at a given location (Supplementary Table 1) while the hypothesis requires the peak to coincide with the lowest $\delta^{30} \mathrm{Si}$ values at $\sim 225 \mathrm{~km}$. Instead, it had passed $>2$ months previously. Further, the rate and magnitude of change $(0.7 \%$ over $\sim 1.5$ months $)$ are stretching plausibility. With the exception of a Siberian catchment with annual permafrost-melt induced switching of DSi sources (Pokrovsky et al., 2013), no published annual river DSi record shows variation of $0.7 \%$ on monthly timescales (Georg et al., 2006; Engstrom et al., 2010; Hughes et al., 2011; Delvaux et al., 2013). Finally, we note that the complex water flow patterns and long residence times of the Delta (Wolski and Murray-Hudson, 2006; Cawley et al., 2012) would result in smoothing of any ostensible historical river signal.

Absorption or desorption of $\mathrm{Si}$ on secondary oxides, particularly Fe-oxides (McKeague and Cline, 1963), may impact the dataset presented here since the lighter isotopes are preferentially absorped (Delstanche et al., 2009; Opfergelt et al., 2009). This is unlikely since (i) the Delta is not an iron-rich environment, and (ii) it is difficult to envisage a mechanism by which substantial active absorption/desorption would be occurring. The magnitude and isotope fractionation associated with $\mathrm{Si}$ sorption to $\mathrm{Fe}$ oxides is to a first order a function of the Fe-oxide structure, solution $\mathrm{pH}$ and DSi concentration (Delstanche et al., 2009). Rapid changes in these parameters are not expected (see Table S2), but would be necessary to induce isotope fractionation.

\section{SYNTHESIS}

Like all fluvial systems, there are two continuously operating sets of processes that together produce the surface water geochemistry - one adding solutes, and one removing them. Despite evapotranspiration-driven increases in surface water DSi concentrations (Fig. 2), the Delta actually experiences net DSi removal - the observed DSi enrichment is less than for other major elements (Section 5.1). In massbalance terms, the processes removing Si from solution outpace those adding $\mathrm{Si}$ to solution. However, the isotopic response is more buffered. If removal was the only process, the residual water should become progressively enriched in the heavier isotopes. In fact, at least in the permanent floodplains, the opposite happens (Fig. 2). Together, the massbalance and isotope constraints permit an interpretation of the Si cycle within the Okavango Delta.

\subsection{The Panhandle}

Relatively stable conditions occur in the riverine Panhandle $(0-100 \mathrm{~km})$ region where floodplain interaction is limited, i.e. the majority of flow is in the main channel and the short residence time allows little possibility for variations. After the Panhandle, flow is not nearly as channelised, so interaction and exchange between surface water and floodplain sediments is much greater, and the data become correspondingly more complex.

\subsection{The Permanent floodplains}

In the permanent floodplains, DSi should increase due to evaporative enrichment (Section 5.1). Instead, concentrations remain relatively stable, while over the same area, DSi $\delta^{30} \mathrm{Si}$ declines by $\sim 0.6 \%$ oo $(100-225 \mathrm{~km})$. In the simplest scenario, this requires removal of DSi with little to no net isotope fractionation (to satisfy the mass balance), plus the input of low $\delta^{30} \mathrm{Si} \mathrm{DSi}$, since no known processes preferentially remove ${ }^{30} \mathrm{Si}$ (to satisfy the isotope mass-balance), bar our newly hypothesised equilibrium isotope exchange during BSi diagenesis.

Given the large vegetation/sediment BSi pool, this is an obvious place to look for a explanation: is there a balance of BSi production and dissolution that can fit the observations? To satisfy the mass-balance requirements, BSi dissolution must be less than production. But to satisfy the isotope mass balance, dissolution should be greater than production, or at least occur with a fractionation greater than that occurring during production, which is not supported by the evidence (Demarest et al., 2009; Section 5.2). We also know production is almost identical to dissolution on decadal to centennial timescales because there is no long-term floodplain $\mathrm{Si}$ storage (Fig. 3, although loss through fluvial or aeolian erosion is isotopically equivalent to long-term storage). Such complete dissolution renders the expression of any existing fractionation impossible and necessarily leads to the production of DSi with $\delta^{30} \mathrm{Si}$ equal to the original BSi. So in the best-case scenario, they are balanced within the constraints imposed by the $\mathrm{Si}$ removal, and the net isotopic effect is close to zero. A source of low $\delta^{30} \mathrm{Si} \mathrm{Si}$ is still required.

Floodplain weathering, for which convincing evidence exists (Section 5.3), may explain the permanent floodplain trend. The quantity of allochthonous material required to dissolve (i.e. 'weather') to produce the observed drop in $\delta^{30} \mathrm{Si}$ can be estimated by isotope mass balance (Eq. (2)):

$\delta_{\text {surf }}=\left(\delta_{\text {inflow }} \cdot X_{\text {inflow }}\right)+\left(\delta_{\text {allocht. }} \cdot X_{\text {allocht. }}\right)$ 
where $X$ is the fraction of total DSi deriving from inflowing DSi or allochthonous sources. Assuming riverine inputs of $9.2 \mathrm{~km}^{3}$ (Section 2) and a mean DSi concentration of $100 \mu \mathrm{M}$, then to change DSi $\delta^{30} \mathrm{Si}$ from $1 \%$ to $0.4 \%$ annually requires the complete dissolution of $\sim 13,800$ tons $\mathrm{SiO}_{2}$, or $\sim 29,700$ tons of an aluminosilicate with a kaolinite stoichiometry $\left(\mathrm{Al}_{2} \mathrm{Si}_{2} \mathrm{O}_{5}(\mathrm{OH})_{4}\right)$, at a $\delta^{30} \mathrm{Si}$ of $-2.0 \%$. This corresponds to about $\sim 10 \%$ of the total annual dust + river suspended sediment (but not including bedload) carried into the Delta, which may include BSi as phytoliths. Though crude, these calculations highlight the feasibility of weathering within the Delta. Since mineral formation and net biological uptake are also occurring here, these numbers represent a minimum estimate. In the absence of other workable hypotheses, we adopt this as the explanation for the decline in surface water $\delta^{30} \mathrm{Si}$ (and therefore surface sediment $\mathrm{BSi} \delta^{30} \mathrm{Si}$ ) over the permanent floodplains $(\sim 100-225 \mathrm{~km})$.

\subsection{The seasonal floodplains}

In the seasonal floodplains both solute concentrations and $\delta^{30} \mathrm{Si}$ increase (from $225 \mathrm{~km}$ onwards), though as noted, this actually reflects net DSi removal. Compared to the permanent floodplains, the situation is more straightforward: DSi is removed, and the $\delta^{30} \mathrm{Si}$ of the remaining DSi increases. The two most plausible Si removal mechanisms are net biological uptake (Section 5.1) or clay mineral neoformation (Section 5.4), but they are difficult to separate with $\mathrm{Si}$ isotopes alone. Since the evidence from the clays, the $\mathrm{Ge} / \mathrm{Si}$ and the porewater chemistry corroborates mineral neoformation, the most likely scenario is that both processes occur. In particular, it is unlikely dissolution of $\mathrm{BSi}$ will equal current production because an unknown quantity of the sediment BSi may be removed by aeolian activity during the dry season, removing it from dissolution.

\subsection{Summary}

A schematic overview is presented in Fig. 7. In summary, the Panhandle area exhibits little variation because of the limited water residence time and the mostly channelised flow. Downstream, in the permanent floodplains, release of DSi from the congruent breakdown of secondary allochthonous minerals provides a source of low $\delta^{30} \mathrm{Si} \mathrm{DSi}$. As the surface waters become progressively evaporatively enriched (towards the seasonal floodplains), they become

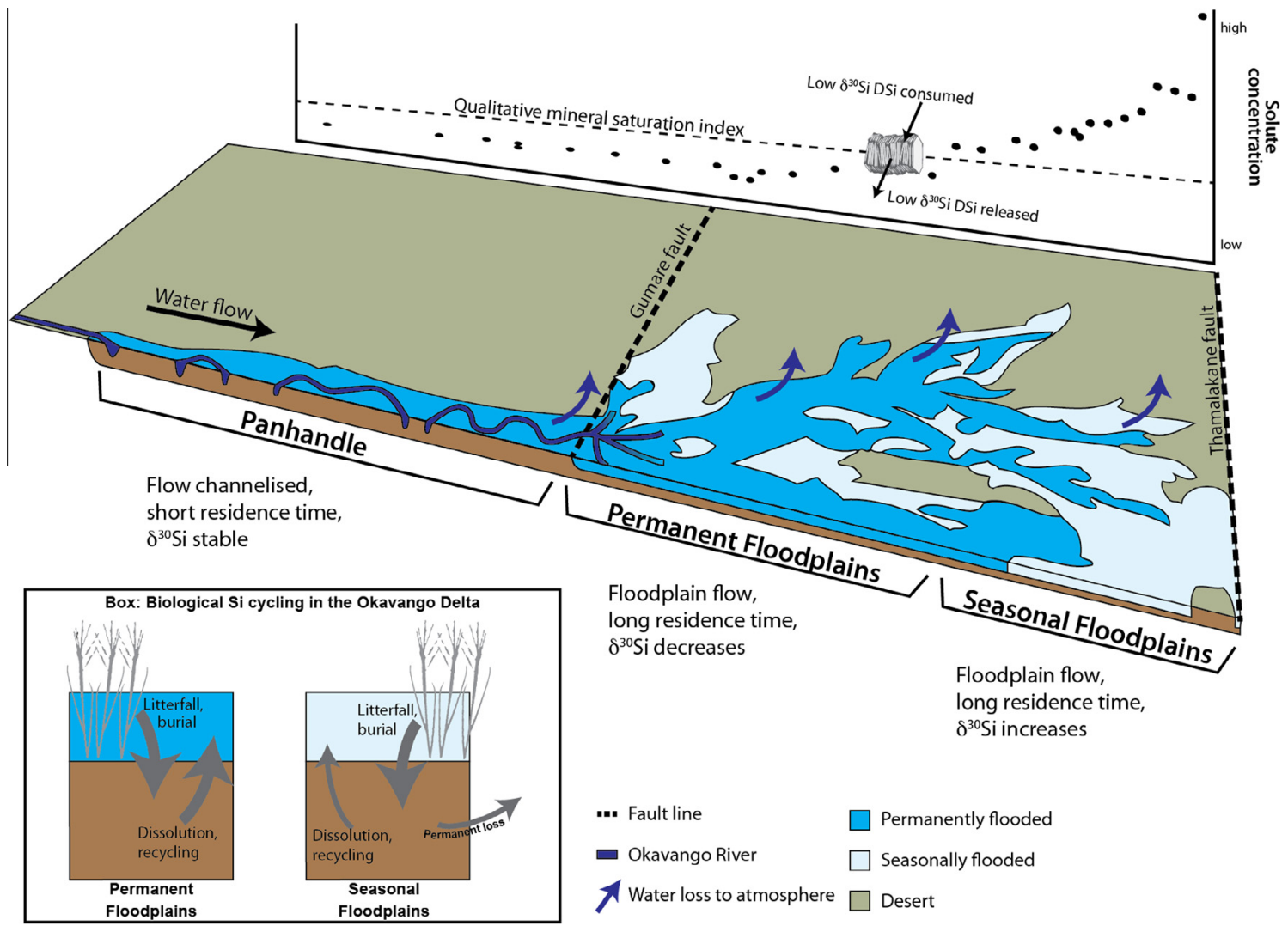

Fig. 7. Conceptual overview of interpretation of processes influencing Si-cycling in the Okavango Delta. As the floodplain waters become progressively enriched due to evapotranspiration, a threshold is crossed where weathering of low $\delta^{30} \mathrm{Si}$ silicate material becomes implausible and instead clay neoformation is favoured. Inset box: biological Si-cycling in the Okavango. BSi production is dominated by vascular plants. In the permanent floodplains, production and dissolution of BSi are at or very close to steady state. Further downstream in the seasonal floodplains, dissolution $<$ production, partly due to aeolian losses in the dry season, and partly because some Si is retained in secondary silicate minerals. 
saturated with respect to the minerals being weathered, and at this point the Delta shifts from net weathering to net DSi removal. This provides a parsimonious, internally consistent explanation for (a) the decline in $\delta^{30} \mathrm{Si}$ of DSi over the permanent floodplains, and (b) the shift to a regime of increasing $\delta^{30} \mathrm{Si}$. Chemical weathering is therefore limited to the generally more dilute surface and upper-porewaters found in the permanent floodplains of the Delta, and is accelerated by the moderately high DOC concentrations. Delta vegetation appears to play a role in determining the location of the shift via its capacity to remove DSi and other solutes from the surface waters. Clay mineral neoformation occurs throughout the Delta - when the geochemistry permits - as evidenced by e.g. the declining $\mathrm{Ge} / \mathrm{Si}$ throughout and the high $\delta^{30} \mathrm{Si}$ clays, but presumably the occurrence of above saturation waters occurs more prevalently downstream.

The Okavango Delta is unusual: primary mineral weathering is minimal, since the available mineral assemblage is almost entirely quartz. It is a nearly-closed system which requires that the majority of solutes are sequestrated somewhere within the Delta. However, the majority of element sequestration occurs beneath the islands (Section 2) and does not impact the geochemistry of the remaining surface waters, so our results will be pertinent elsewhere. We suggest the Okavango Delta can be conceptualised as a space-for-time substitute for other, more typical riverfloodplain systems, where differences in biogeochemical processing are observed between the flood pulse and recession (e.g. Valett et al., 2005; Scott et al., 2014). Disentangling biological activity from weathering processes is not straightforward, but can be achieved using $\mathrm{Si}$ isotopes as a tracer. Our results add to a growing body of literature that identifies floodplains as biogeochemical reactors.

\section{ACKNOWLEDGEMENTS}

We thank Ian Patmore and Anson Mackay at UCL for the loan of equipment and Celine Liorzou at IUEM and Karin Holm at ITM, Stockholm for assistance with laboratory analysis. A National Geographic Global Exploration Fund award made the 2012 fieldwork possible. PJF would like to acknowledge the ClimBEco Graduate School for funding a research visit and LUCCI for contributing to analytical costs. DJC acknowledges financial support from the Wallenberg Foundation and the Swedish National Science Foundation (VR) that contributed towards this research. This analysis was also supported by a LEFE CYBER grant (SiBRED) to CDLR. ES acknowledges support from BELSPO for funding SOGLO and EU Marie Curie Actions for funding Hobits and JS acknowledges FWO for a travel grant. Hanna Alfredson, Wim Clymans and Guillaume Fontorbe are thanked for stimulating discussions and useful comments on this manuscript. We thank Andrew Jacobson for editorial handling and Maarten Lupker and two anonymous reviewers whose comments greatly benefited the manuscript.

\section{APPENDIX A. SUPPLEMENTARY DATA}

Supplementary data associated with this article can be found, in the online version, at http://dx.doi.org/10.1016/ j.gca.2014.07.007.

\section{REFERENCES}

Basile-Doelsch I., Meunier J. D. and Parron C. (2005) Another continental pool in the terrestrial silicon cycle. Nature 433, 399402.

Bauer P., Supper R., Zimmermann S. and Kinzelbach W. (2006) Geoelectrical imaging of groundwater salinization in the Okavango Delta, Botswana. J. Appl. Geophys. 60, 126-141.

Bauer P., Thabeng G., Stauffer F. and Kinzelbach W. (2004) Estimation of the evapotranspiration rate from diurnal groundwater level fluctuations in the Okavango Delta, Botswana. $J$. Hydrol. 288, 344-355.

Beaulieu E., Godderis Y., Labat D., Roelandt C., Oliva P. and Guerrero B. (2010) Impact of atmospheric $\mathrm{CO}_{2}$ levels on continental silicate weathering. Geochem. Geophys. Geosyst. 11, 18.

Bernal B. and Mitsch W. J. (2013) Carbon sequestration in freshwater wetlands in Costa Rica and Botswana. Biogeochemistry 115, 77-93.

Berner R. A., Lasaga A. C. and Garrels R. M. (1983) The carbonate-silicate geochemical cycle and its effect on atmospheric carbon dioxide over the past 100 million years. Am. J. Sci. 283, 641-683.

Bigeleisen J. (1965) Chemistry of Isotopes: Isotope chemistry has opened new areas of chemical physics, geochemistry, and molecular biology. Science 147, 463-471.

Bouchez J., Gaillardet J., Lupker M., Louvat P., France-Lanord C., Maurice L., Armijos E. and Moquet J.-S. (2012) Floodplains of large rivers: weathering reactors or simple silos? Chem. Geol. 332-333, 166-184.

Brewer T. S., Leng M. J., Mackay A. W., Lamb A. L., Tyler J. J. and Marsh N. G. (2008) Unravelling contamination signals in biogenic silica oxygen isotope composition: the role of major and trace element geochemistry. J. Quaternary Sci. 23, 321-330.

Bricker O. P., Jones B. F. and Bowser C. J. (2005) Mass-balance approach to interpreting weathering reactions in watershed systems. In Surface and Ground Water, Weathering, and Soils (ed. J. I. Drever). Elsevier, London, pp. 119-132.

Bristow T. F. and Milliken R. E. (2011) Terrestrial perspective on authigenic clay mineral production in ancient Martian lakes. Clays Clay Miner. 59, 339-358.

Cardinal D., Alleman L. Y., de Jong J., Ziegler K. and Andre L. (2003) Isotopic composition of silicon measured by multicollector plasma source mass spectrometry in dry plasma mode. $J$. Anal. At. Spectrom. 18, 213-218.

Cardinal D., Gaillardet J., Hughes H. J., Opfergelt S. and Andre L. (2010) Contrasting silicon isotope signatures in rivers from the Congo Basin and the specific behaviour of organic-rich waters. Geophys. Res. Lett. 37.

Cawley K., Wolski P., Mladenov N. and Jaffé R. (2012) Dissolved organic matter biogeochemistry along a transect of the Okavango Delta, Botswana. Wetlands 32, 475-486.

Cockerton H. E., Street-Perrott F. A., Leng M. J., Barker P. A., Horstwood M. S. A. and Pashley V. (2013) Stable-isotope (H, $\mathrm{O}$, and $\mathrm{Si}$ ) evidence for seasonal variations in hydrology and $\mathrm{Si}$ cycling from modern waters in the Nile Basin: implications for interpreting the Quaternary record. Quatern. Sci. Rev. 66, $4-21$.

Cornelis J. T., Delvaux B., Cardinal D., Andre L., Ranger J. and Opfergelt S. (2010) Tracing mechanisms controlling the release of dissolved silicon in forest soil solutions using $\mathrm{Si}$ isotopes and Ge/Si ratios. Geochim. Cosmochim. Acta 74, 3913-3924.

Cornelis J. T., Delvaux B., Georg R. B., Lucas Y., Ranger J. and Opfergelt S. (2011) Tracing the origin of dissolved silicon transferred from various soil-plant systems towards rivers: a review. Biogeosciences 8, 89-112. 
De La Rocha C. L., Brzezinski M. A. and DeNiro M. J. (1996) Purification, recovery, and laser-driven fluorination of silicon from dissolved and particulate silica for the measurement of natural stable isotope abundances. Anal. Chem. 68, 3746-3750.

De La Rocha C. L., Brzezinski M. A. and DeNiro M. J. (2000) A first look at the distribution of the stable isotopes of silicon in natural waters. Geochim. Cosmochim. Acta 64, 2467-2477.

De La Rocha C. L., Bescont P., Croguennoc A. and Ponzevera E. (2011) The silicon isotopic composition of surface waters in the Atlantic and Indian sectors of the Southern Ocean. Geochim. Cosmochim. Acta 75, 5283-5295.

De La Rocha C. L., Brzezinski M. A., DeNiro M. J. and Shemesh A. (1998) Silicon-isotope composition of diatoms as an indicator of past oceanic change. Nature 395, 680-683.

Delstanche S., Opfergelt S., Cardinal D., Elsass F., André L. and Delvaux B. (2009) Silicon isotopic fractionation during adsorption of aqueous monosilicic acid onto iron oxide. Geochim. Cosmochim. Acta 73, 923-934.

Delvaux C., Cardinal D., Carbonnel V., Chou L., Hughes H. J. and André L. (2013) Controls on riverine $\delta^{30} \mathrm{Si}$ signatures in a temperate watershed under high anthropogenic pressure (Scheldt - Belgium). J. Mar. Syst. 128, 40-51.

Delvigne C., Opfergelt S., Cardinal D., Delvaux B. and Andre L. (2009) Distinct silicon and germanium pathways in the soilplant system: evidence from banana and horsetail. J. Geophys. Res. Biogeosci. 114, 11.

Demarest M. S., Brzezinski M. A. and Beucher C. P. (2009) Fractionation of silicon isotopes during biogenic silica dissolution. Geochim. Cosmochim. Acta 73, 5572-5583.

DeMaster D. J. (1991) Measuring biogenic silica in marinesediments and suspended matter. In Marine Particles: Analysis and Characterization (eds. D. C. Hurd and D. W. Spencer). Amer Geophysical Union, Washington, pp. 363-367.

Ding T., Jiang M. S., Wan D., Li Y., Li J., Song H., Liu Z. and Yao X. (1996) Silicon Isotope Geochemistry. Geological Publishing House, Beijing, China.

Ding T. P., Tian S. H., Sun L., Wu L. H., Zhou J. X. and Chen Z. Y. (2008) Silicon isotope fractionation between rice plants and nutrient solution and its significance to the study of the silicon cycle. Geochim. Cosmochim. Acta 72, 5600-5615.

Douthitt C. B. (1982) The geochemistry of the stable isotopes of silicon. Geochim. Cosmochim. Acta 46, 1449-1458.

Engström E., Rodushkin I., Baxter D. C. and Öhlander B. (2005) Chromatographic purification for the determination of dissolved silicon isotopic compositions in natural waters by highresolution multicollector inductively coupled plasma mass spectrometry. Anal. Chem. 78, 250-257.

Engstrom E., Rodushkin I., Ingri J., Baxter D. C., Ecke F., Osterlund H. and Ohlander B. (2010) Temporal isotopic variations of dissolved silicon in a pristine boreal river. Chem. Geol. 271, 142-152.

Epstein E. (1999) Silicon. Ann. Rev. Plant Physiol. Plant Mol. Biol. 50, 641-664.

Fontorbe G., De La Rocha C. L., Chapman H. J. and Bickle M. J. (2013) The silicon isotopic composition of the ganges and its tributaries. Earth Planet. Sci. Lett. 381, 21-30.

Furquim S., Graham R., Barbiéro L., Queiroz Neto J. and VidalTorrado P. (2010a) Soil mineral genesis and distribution in a saline lake landscape of the Pantanal Wetland, Brazil. Geoderma 154, 518-528.

Furquim S. A. C., Barbiero L., Graham R. C., Neto J., Ferreira R. P. D. and Furian S. (2010b) Neoformation of micas in soils surrounding an alkaline-saline lake of Pantanal wetland, Brazil. Geoderma 158, 331-342.
Gaillardet J., Dupre B., Louvat P. and Allegre C. J. (1999) Global silicate weathering and $\mathrm{CO}_{2}$ consumption rates deduced from the chemistry of large rivers. Chem. Geol. 159, 3-30.

Galy A. and France-Lanord C. (1999) Weathering processes in the Ganges-Brahmaputra basin and the riverine alkalinity budget. Chem. Geol. 159, 31-60.

Garrels R.M. and Mackenzie F.T. (1967) Origin of the Chemical Compositions of Some Springs and Lakes. In Equilibrium Concepts in Natural Water Systems. American Chemical Society, pp. 222-242.

Garstang M., Ellery W. N., McCarthy T. S., Scholes M. C., Scholes R. J., Swap R. J. and Tyson P. D. (1998) The contribution of aerosol- and water-borne nutrients to the functioning of the Okavango Delta. S. Afr. J. Sci. 94, 223.

Georg R. B., Reynolds B. C., Frank M. and Halliday A. N. (2006) Mechanisms controlling the silicon isotopic compositions of river waters. Earth Planet. Sci. Lett. 249, 290-306.

Gieske A. (1997) Modelling outflow from the Jao/Boro River system in the Okavango Delta, Botswana. J. Hydrol. 193, 214 239.

Gumbricht T., McCarthy T. S. and Bauer P. (2005) The microtopography of the wetlands of the Okavango Delta, Botswana. Earth Surf. Proc. Land. 30, 27-39.

Gumbricht T., Wolski P., Frost P. and McCarthy T. S. (2004) Forecasting the spatial extent of the annual flood in the Okavango delta, Botswana. J. Hydrol. 290, 178-191.

House W. A., Denison F. H., Warwick M. S. and Zhmud B. V. (2000) Dissolution of silica and the development of concentration profiles in freshwater sediments. Appl. Geochem. 15, 425438.

Hughes H. J., Sondag F., Cocquyt C., Laraque A., Pandi A., Andre L. and Cardinal D. (2011) Effect of seasonal biogenic silica variations on dissolved silicon fluxes and isotopic signatures in the Congo River. Limnol. Oceanogr. 56, 551-561.

Hughes H. J., Sondag F., Santos R. V., André L. and Cardinal D. (2013) The riverine silicon isotope composition of the Amazon Basin. Geochim. Cosmochim. Acta 121, 637-651.

Humphries M., Kindness A., Ellery W. and Hughes J. (2011) Water chemistry and effect of evapotranspiration on chemical sedimentation on the Mkuze River floodplain, South Africa. $J$. Arid Environ. 75, 555-565.

Humphries M. S., Kindness A., Ellery W. N. and Hughes J. C. (2010) Sediment geochemistry, mineral precipitation and clay neoformation on the Mkuze River floodplain, South Africa. Geoderma 157, 15-26.

Humphries M. S., McCarthy T. S., Cooper G. R. J., Stewart R. A. and Stewart R. D. (2014) The role of airborne dust in the growth of tree islands in the Okavango Delta, Botswana. Geomorphology 206, 307-317.

Johnsson M. J. and Meade R. H. (1990) Chemical weathering of fluvial sediments during alluvial storage: the Macuapanim Island point bar, Solimões River, Brazil. J. Sediment. Res. 60.

Jones M. J. (2010) The groundwater hydrology of the Okavango. FAO internal reports, Okavango River Basin Water Commission (OKACOM), Maun, Botswana.

Kihwele E., Mnaya B., Meng'ataki G., Birkett C. and Wolanski E. (2012) The role of vegetation in the water budget of the Usangu wetlands, Tanzania. Wetlands Ecol. Manage. 20, 389-398.

Klančnik K., Vogel-Mikuš K. and Gaberščik A. (2013) Silicified structures affect leaf optical properties in grasses and sedge. $J$. Photochem. Photobiol. B 130, 1-10.

Krah M., McCarthy T. S., Huntsman-Mapila P., Wolski P., Annegarn H. and Sethebe K. (2006) Nutrient budget in the seasonal wetland of the Okavango Delta, Botswana. Wetlands Ecol. Manage. 14, 253-267. 
Kurtz A. C., Derry L. A. and Chadwick O. A. (2002) Germaniumsilicon fractionation in the weathering environment. Geochim. Cosmochim. Acta 66, 1525-1537.

Lancaster N. (1986) Grain-size characteristics of linear dunes in the southwestern Kalahari. J. Sediment. Res. 56, 395-400.

Lewis B. L., Andreae M. O., Froelich P. N. and Mortlock R. A. (1988) A review of the biogeochemistry of germanium in natural waters. Sci. Total Environ. 73, 107-120.

Livingstone I., Bullard J. E., Wiggs G. F. S. and Thomas D. S. T. (1999) Grain-size variation on dunes in the Southwest Kalahari, Southern Africa. J. Sediment. Res. 69, 546-552.

Lupker M., France-Lanord C., Galy V., Lavé J., Gaillardet J., Gajurel A. P., Guilmette C., Rahman M., Singh S. K. and Sinha R. (2012) Predominant floodplain over mountain weathering of Himalayan sediments (Ganga basin). Geochim. Cosmochim. Acta 84, 410-432.

Ma J. F. and Yamaji N. (2008) Functions and transport of silicon in plants. Cell. Mol. Life Sci. 65, 3049-3057.

Mackay A. W., Davidson T., Wolski P., Mazebedi R., Masamba W. R. L., Huntsman-Mapila P. and Todd M. (2011) Spatial and seasonal variability in surface water chemistry in the Okavango Delta, Botswana: a multivariate approach. Wetlands 31, 815-829.

Maher K., Steefel C. I., White A. F. and Stonestrom D. A. (2009) The role of reaction affinity and secondary minerals in regulating chemical weathering rates at the Santa Cruz Soil Chronosequence, California. Geochim. Cosmochim. Acta 73, 2804-2831.

Mackenzie F. T. and Garrels R. M. (1966) Chemical mass balance between rivers and oceans. Am. J. Sci. 264, 507-525.

McCarthy T., Stanistreet I. and Cairncross B. (1991a) The sedimentary dynamics of active fluvial channels on the Okavango fan, Botswana. Sedimentology 38, 471-487.

McCarthy T. S., Barry M., Bloem A., Ellery W. N., Heister H., Merry C. L., Röther H. and Sternberg H. (1997) The gradient of the Okavango fan, Botswana, and its sedimentological and tectonic implications. J. Afr. Earth Sci. 24, 65-78.

McCarthy T. S. and Ellery W. N. (1998) The Okavango Delta. Trans. R. Soc. S. Afr. 53, 157-182.

McCarthy T. S., Humphries M. S., Mahomed I., Le Roux P. and Verhagen B. T. (2012) Island forming processes in the Okavango Delta, Botswana. Geomorphology 179, 249-257.

McCarthy T. S., McIver J. R., Cairncross B., Ellery W. N. and Ellery K. (1989) The inorganic chemistry of peat from the Maunachira channel-swamp system, Okavango Delta, Botswana. Geochim. Cosmochim. Acta 53, 1077-1089.

McCarthy T. S., Stanistreet I. G. and Cairncross B. (1991b) The sedimentary dynamics of active fluvial channels on the Okavango fan, Botswana. Sedimentology 38, 471-487.

MacDonald R. and McLaughlin F. (1982) The effect of storage by freezing on dissolved inorganic phosphate, nitrate and reactive silicate for samples from coastal and estuarine waters. Water Res. 16, 95-104.

Mariotti A., Germon J. C., Hubert P., Kaiser P., Letolle R., Tardieux A. and Tardieux P. (1981) Experimental determination of nitrogen kinetic isotope fractionation: some principles; illustration for the denitrification and nitrification processes. Plant Soil 62, 413-430.

McKeague J. A. and Cline M. G. (1963) Silica in soil solutions: II. The adsorption of monosilicic acid by soil and by other substances. Can. J. Soil Sci. 43, 83-96.

Michalopoulos P. and Aller R. C. (1995) Rapid clay mineral formation in Amazon Delta sediments - reverse weathering and oceanic elemental cycles. Science 270, 614-617.

Milzow C., Kgotlhang L., Bauer-Gottwein P., Meier P. and Kinzelbach W. (2009a) Regional review: the hydrology of the
Okavango Delta, Botswana-processes, data and modelling. Hydrogeol. J. 17, 1297-1328.

Milzow C., Kgotlhang L., Kinzelbach W., Meier P. and BauerGottwein P. (2009b) The role of remote sensing in hydrological modelling of the Okavango Delta, Botswana. J. Environ. Manage. 90, 2252-2260.

Mladenov N., McKnight D. M., Macko S. A., Norris M., Cory R. M. and Ramberg L. (2007) Chemical characterization of DOM in channels of a seasonal wetland. Aquat. Sci. 69, 456-471.

Mladenov N., McKnight D. M., Wolski P. and Ramberg L. (2005) Effects of annual flooding on dissolved organic carbon dynamics within a pristine wetland, the Okavango Delta, Botswana. Wetlands 25, 622-638.

Moore J., Jacobson A. D., Holmden C. and Craw D. (2013) Tracking the relationship between mountain uplift, silicate weathering, and long-term $\mathrm{CO}_{2}$ consumption with $\mathrm{Ca}$ isotopes: Southern Alps, New Zealand. Chem. Geol. 341, 110-127.

Oelze M., von Blanckenburg F., Hoellen D., Dietzel M. and Bouchez J. (2014) $\mathrm{Si}$ stable isotope fractionation during adsorption and the competition between kinetic and equilibrium isotope fractionation: Implications for weathering systems. Chem. Geol. 380, 161-171.

Oliva P., Viers J., Dupré B., Fortuné J. P., Martin F., Braun J. J., Nahon D. and Robain H. (1999) The effect of organic matter on chemical weathering: study of a small tropical watershed: nsimizoétélé site, Cameroon. Geochim. Cosmochim. Acta 63, 40134035.

Opfergelt S., de Bournonville G., Cardinal D., André L., Delstanche S. and Delvaux B. (2009) Impact of soil weathering degree on silicon isotopic fractionation during adsorption onto iron oxides in basaltic ash soils, Cameroon. Geochim. Cosmochim. Acta 73, 7226-7240.

Opfergelt S., Cardinal D., André L., Delvigne C., Bremond L. and Delvaux B. (2010) Variations of $\delta^{30} \mathrm{Si}$ and $\mathrm{Ge} / \mathrm{Si}$ with weathering and biogenic input in tropical basaltic ash soils under monoculture. Geochim. Cosmochim. Acta 74, 225-240.

Opfergelt S., Cardinal D., Henriet C., Draye X., André L. and Delvaux B. (2006) Silicon isotopic fractionation by banana (Musa spp.) grown in a continuous nutrient flow device. Plant Soil 285, 333-345.

Opfergelt S. and Delmelle P. (2012) Silicon isotopes and continental weathering processes: assessing controls on Si transfer to the ocean. C. R. Geosci. 344, 723-738.

Opfergelt S., Georg R. B., Delvaux B., Cabidoche Y. M., Burton K. W. and Halliday A. N. (2012) Silicon isotopes and the tracing of desilication in volcanic soil weathering sequences, Guadeloupe. Chem. Geol. 326-327, 113-122.

Pearce C. R., Saldi G. D., Schott J. and Oelkers E. H. (2012) Isotopic fractionation during congruent dissolution, precipitation and at equilibrium: evidence from $\mathrm{Mg}$ isotopes. Geochim. Cosmochim. Acta 92, 170-183.

Pogge von Strandmann P. A. E., Opfergelt S., Lai Y.-J., Sigfússon B., Gislason S. R. and Burton K. W. (2012) Lithium, magnesium and silicon isotope behaviour accompanying weathering in a basaltic soil and pore water profile in Iceland. Earth Planet. Sci. Lett. 339-340, 11-23.

Pokrovsky O. S., Reynolds B. C., Prokushkin A. S., Schott J. and Viers J. (2013) Silicon isotope variations in Central Siberian rivers during basalt weathering in permafrost-dominated larch forests. Chem. Geol. 355, 103-116.

Ramberg L. and Wolski P. (2008) Growing islands and sinking solutes: processes maintaining the endorheic Okavango Delta as a freshwater system. Plant Ecol. 196, 215-231.

Ramberg L., Wolski P. and Krah M. (2006) Water balance and infiltration in a seasonal floodplain in the Okavango Delta, Botswana. Wetlands 26, 677-690. 
Righi D. and Meunier A. (1995) Origin of clays by rock weathering and soil formation. In Origin and Mineralogy of Clays (ed. B. Velde). Springer, Berlin Heidelberg, pp. 43-161.

Sagan C. and Mullen G. (1972) Earth and mars: evolution of atmospheres and surface temperatures. Science 177, 52-56.

Savage P. S., Georg R. B., Williams H. M. and Halliday A. N. (2013) The silicon isotope composition of the upper continental crust. Geochim. Cosmochim. Acta 109, 384-399.

Sawula G. and Martins E. (1991) Major ion chemistry of the lower Boro River, Okavango Delta, Botswana. Freshw. Biol. 26, 481-493.

Schaller J. and Struyf E. (2013) Silicon controls microbial decay and nutrient release of grass litter during aquatic decomposition. Hydrobiologia 709, 201-212.

Schoelynck J., Bal K., Backx H., Okruszko T., Meire P. and Struyf S. (2010) Silica uptake in aquatic and wetland macrophytes: a strategic choice between silica, lignin and cellulose? New Phytol. 186, 385-391.

Shemesh A., Mortlock R. A., Smith R. J. and Froelich P. N. (1988) Determination of $\mathrm{Ge} / \mathrm{Si}$ in marine siliceous microfossils: separation, cleaning and dissolution of diatoms and radiolaria. Mar. Chem. 25, 305-323.

Scribner A. M., Kurtz A. C. and Chadwick O. A. (2006) Germanium sequestration by soil: targeting the roles of secondary clays and Fe-oxyhydroxides. Earth Planet. Sci. Lett. 243, 760-770.

Scott D. T., Keim R. F., Edwards B. L., Jones C. N. and Kroes D. E. (2014) Floodplain biogeochemical processing of floodwaters in the Atchafalaya River Basin during the Mississippi River flood of 2011. J. Geophys. Res. Biogeosci. 119, 2013JG002477.

Seeberg-Elverfeldt J., Schluter M., Feseker T. and Kolling M. (2005) Rhizon sampling of porewaters near the sediment-water interface of aquatic systems. Limnol. Oceanogr. Meth. 3, 361371.

Souza-Júnior V. S. d., Vidal-Torrado P., Garcia-González M. T., Macías F. and Otero X. L. (2010) Smectite in mangrove soils of the State of São Paulo, Brazil. Sci. Agric. 67, 47-52.

Steinhoefel G., Breuer J., von Blanckenburg F., Horn I., Kaczorek D. and Sommer M. (2011) Micrometer silicon isotope diagnostics of soils by UV femtosecond laser ablation. Chem. Geol. 286, 280-289.

Strickland J. D. H. and Parsons T. R. (1968) Determination of reactive silicate. A Practical Handbook of Seawater Analysis. Fisheries Research Board of Canada, pp. 65-70.

Struyf E., Van Damme S., Gribsholt B., Bal K., Beauchard O., Middelburg J. J. and Meire P. (2007) Phragmites australis and silica cycling in tidal wetlands. Aquat. Bot. 87, 134-140.

Struyf E., Mosimane K., Van Pelt D., Murray-Hudson M., Meire P., Frings P., Wolski P., Schaller J., Gondwe M., Schoelynck J. and Conley D. J. (submitted) The role of vegetation in the Okavango Delta silica sink. Submitted to Wetlands.
Sun X., Olofsson M., Andersson P. S., Fry B., Legrand C., Humborg C. and Mörth C.-M. (2014) Effects of growth and dissolution on the fractionation of silicon isotopes by estuarine diatoms. Geochim. Cosmochim. Acta 130, 156-166.

Valett H., Baker M., Morrice J., Crawford C., Molles, Jr, M., Dahm C., Moyer D., Thibault J. and Ellis L. M. (2005) Biogeochemical and metabolic responses to the flood pulse in a semiarid floodplain. Ecology 86, 220-234.

Viers J., Dupré B., Polvé M., Schott J., Dandurand J.-L. and Braun J.-J. (1997) Chemical weathering in the drainage basin of a tropical watershed (Nsimi-Zoetele site, Cameroon): comparison between organic-poor and organic-rich waters. Chem. Geol. 140, 181-206.

Walker J. C. G., Hays P. B. and Kasting J. F. (1981) A negative feedback mechanism for the long-term stabilization of Earths surface-temperature. J. Geophys. Res. Oceans Atmos. 86, 9776 9782.

Wetzel F., de Souza G. F. and Reynolds B. C. (2014) What controls silicon isotope fractionation during dissolution of diatom opal? Geochim. Cosmochim. Acta 131, 128-137.

White A. F., Schulz M. S., Stonestrom D. A., Vivit D. V., Fitzpatrick J., Bullen T. D., Maher K. and Blum A. E. (2009) Chemical weathering of a marine terrace chronosequence, Santa Cruz, California. Part II: solute profiles, gradients and the comparisons of contemporary and long-term weathering rates. Geochim. Cosmochim. Acta 73, 2769-2803.

Wolski P. and Murray-Hudson M. (2006) Flooding dynamics in a large low-gradient alluvial fan, the Okavango Delta, Botswana, from analysis and interpretation of a 30-year hydrometric record. Hydrol. Earth Syst. Sci. 10, 127-137.

Wolski P. and Savenije H. H. G. (2006) Dynamics of floodplainisland groundwater flow in the Okavango Delta, Botswana. $J$. Hydrol. 320, 283-301.

Yang L. and Steefel C. I. (2008) Kaolinite dissolution and precipitation kinetics at $22{ }^{\circ} \mathrm{C}$ and $\mathrm{pH} 4$. Geochim. Cosmochim. Acta 72, 99-116.

Ziegler K., Chadwick O. A., Brzezinski M. A. and Kelly E. F. (2005a) Natural variations of $\delta^{30} \mathrm{Si}$ ratios during progressive basalt weathering, Hawaiian Islands. Geochim. Cosmochim. Acta 69, 4597-4610.

Ziegler K., Chadwick O. A., White A. F. and Brzezinski M. A. (2005b) $\delta^{30} \mathrm{Si}$ systematics in a granitic saprolite, Puerto Rico. Geology 33, 817-820.

Zimmermann S., Bauer P., Held R., Kinzelbach W. and Walther J. H. (2006) Salt transport on islands in the Okavango Delta: numerical investigations. Adv. Water Resour. 29, 11-29.

Associate editor: Andrew D. Jacobson 